\title{
Strategies for recovery of imbalanced full-scale biogas reactor feeding with palm oil mill effluent
}

\author{
Nantharat Wongfaed ${ }^{\text {Equal first author, } 1}{ }^{\text {, Prawit Kongjan }}{ }^{2}$, Wantanasak Suksong $^{3}$, Poonsuk Prasertsan ${ }^{4}$, Sompong O- \\ Thong Corresp. Equal first author, 1, 5 \\ ${ }^{1}$ Biotechnology Program, Faculty of Science, Thaksin University, Phatthalung 93210, Thailand \\ Department of Science, Faculty of Science and Technology, Prince of Songkla University, Pattani 94000, Thailand \\ 3 School of Bioresources and Technology, King Mongkut's University of Technology, Thonburi, Bangkok 10150, Thailand \\ 4 Research and Development Office, Prince of Songkla University, Songkhla 90000, Thailand \\ 5 International College, Thaksin University, Songkhla 90000, Thailand \\ Corresponding Author: Sompong O-Thong \\ Email address: sompong.o@tsu.ac.th
}

Background: Full-scale biogas production from palm oil mill effluent (POME) was inhibited by low pH and highly volatile fatty acid (VFA) accumulation. Three strategies were investigated for recovering the anaerobic digestion (AD) imbalance on biogas production, namely the dilution method (tap water vs. biogas effluent), pH adjustment method $\left(\mathrm{NaOH}, \mathrm{NaHCO}_{3}, \mathrm{Ca}(\mathrm{OH})_{2}\right.$, oil palm ash), and bioaugmentation (active methane-producing sludge) method. The highly economical and feasible method was selected and validated in a full-scale application.

Results: The inhibited sludge from a full-scale biogas reactor could be recovered within 30-36 days by employing various strategies. Dilution of the inhibited sludge with biogas effluent at a ratio of $8: 2, \mathrm{pH}$ adjustment with $0.14 \% \mathrm{w} / \mathrm{v} \mathrm{NaOH}$, and $8.0 \% \mathrm{w} / \mathrm{v}$ oil palm ash were considered to be more economically feasible than other strategies tested (dilution with tap water, or $\mathrm{pH}$ adjustment with $0.50 \% \mathrm{w} / \mathrm{v} \mathrm{Ca}(\mathrm{OH})_{2}$, or $1.25 \% \mathrm{NaHCO}_{3}$ and bioaugmentation) with a recovery time of 30-36 days. The recovered biogas reactor exhibited a 35-83\% higher methane yield than self-recovery, with a significantly increased hydrolysis constant $\left(\mathrm{k}_{\mathrm{H}}\right)$ and specific methanogenic activity (SMA). The population of Clostridium sp., Bacillus sp., and Methanosarcina sp. increased in the recovered sludge. The imbalanced full-scale hybrid cover lagoon reactor was recovered within 15 days by dilution with biogas effluent at a ratio of 8:2 and a better result than the lab-scale test (36 days).

Conclusion: Dilution of the inhibited sludge with biogas effluent could recover the imbalance of the fullscale POME-biogas reactor with economically feasible and high biogas production performance. 


\section{Strategies for recovery of imbalanced full-scale biogas reactor feeding with}

\section{2 palm oil mill effluent}

3

4 Nantharat Wongfaed ${ }^{1}$, Prawit Kongjan ${ }^{2}$, Wantanasak Suksong ${ }^{3}$, Poonsuk Prasertsan ${ }^{4}$, and

5 Sompong O-Thong $1,5, *$

6

$7 \quad{ }^{1}$ Biotechnology Program, Faculty of Science, Thaksin University, Phatthalung 93210 Thailand

82 Department of Science, Faculty of Science and Technology, Prince of Songkla University,

9 Pattani 94000, Thailand

$10{ }^{3}$ School of Bioresources and Technology, King Mongkut's University of Technology Thonburi,

11 Bangkok 10150 Thailand

$12{ }^{4}$ Research and Development Office, Prince of Songkla University, Songkhla 90112, Thailand

$13{ }^{5}$ International College, Thaksin University, Songkhla 90000, Thailand

14

15 Corresponding author: Sompong O-Thong

16 International College, Thaksin University, Songkhla 90000, Thailand

17 sompong.o@tsu.ac.th (S. O-Thong) 
30 Abstract

31 Background: Full-scale biogas production from palm oil mill effluent (POME) was inhibited by 32 low $\mathrm{pH}$ and highly volatile fatty acid (VFA) accumulation. Three strategies were investigated for 33 recovering the anaerobic digestion (AD) imbalance on biogas production, namely the dilution 34 method (tap water vs. biogas effluent), $\mathrm{pH}$ adjustment method $\left(\mathrm{NaOH}, \mathrm{NaHCO}_{3}, \mathrm{Ca}(\mathrm{OH})_{2}\right.$, oil palm ash), and bioaugmentation (active methane-producing sludge) method. The highly economical and feasible method was selected and validated in a full-scale application.

Results: The inhibited sludge from a full-scale biogas reactor could be recovered within 30-36 days by employing various strategies. Dilution of the inhibited sludge with biogas effluent at a ratio of $8: 2, \mathrm{pH}$ adjustment with $0.14 \% \mathrm{w} / \mathrm{v} \mathrm{NaOH}$, and $8.0 \% \mathrm{w} / \mathrm{v}$ oil palm ash were considered to be more economically feasible than other strategies tested (dilution with tap water, or $\mathrm{pH}$ adjustment with $0.50 \% \mathrm{w} / \mathrm{v} \mathrm{Ca}(\mathrm{OH})_{2}$, or $1.25 \% \mathrm{NaHCO}_{3}$ and bioaugmentation) with a recovery time of 30-36 days. The recovered biogas reactor exhibited a 35-83\% higher methane yield than self-recovery, with a significantly increased hydrolysis constant $\left(\mathrm{k}_{\mathrm{H}}\right)$ and specific methanogenic activity (SMA). The population of Clostridium sp., Bacillus sp., and Methanosarcina sp. increased in the recovered sludge. The imbalanced full-scale hybrid cover lagoon reactor was recovered within 15 days by dilution with biogas effluent at a ratio of 8:2 and a better result than the lab-scale test (36 days).

Conclusion: Dilution of the inhibited sludge with biogas effluent could recover the imbalance of the full-scale POME-biogas reactor with economically feasible and high biogas production performance.

Keywords: acidified inhibition, full-scale biogas plant, microbial community, organic overloading, palm oil mill effluent, recovery strategy 
60

61

62

63

64

65

66

67

68

69

70

\section{Introduction}

Palm oil mill effluent (POME) is the main wastewater generated from the palm oil extraction plant which is mostly treated through an anaerobic process with energy production in terms of biogas (Wu et al., 2010). Biogas has been identified as one of the most promising renewable technologies based on the socio-economic analysis. The application of biogas production technology to treat POME has expanded in response to demand. Unforeseen process-related accidents occur regularly in biogas plants, where the process is inhibited, and biogas production is reduced. The long-term operation of commercial biogas reactor feeding with POME was confronted with process imbalance by volatile fatty acid (VFA) inhibition, long-chain fatty acids (LCFAs) inhibition, low pH inhibition, and foaming (Wongfaed et al., 2015; Wongfaed et al., 2020). The imbalanced biogas reactor resulted in a reduction of biogas production, reduction of chemical oxygen demand (COD) removal efficiency, and failure of the anaerobic digestion (AD) process (Joo-Hwa \& Xiyue, 2000; Menardo et al., 2011). The imbalanced biogas reactor feeding with POME was mainly caused by fluctuations in POME composition and volume that varied depending on the quality of palm fruit, season, harvesting period, and extraction process. The feedstock composition and organic loading rate (OLR) were affected in both bacterial and archaeal communities in the AD process (Supaphol et al., 2011; Xia et al., 2012). In addition, their fluctuations always caused the process imbalance of high strength feedstock resulting in unstable biogas production performance (Joo-Hwa \& Xiyue, 2000). Moreover, the overloading of the substrate could inhibit the AD process, resulting in losses of methane yield of up to $30 \%$ (Fotidis et al., 2014). Reactor acidification by organic overload is one of the most common reasons for this AD process imbalance (Akuzawa et al., 2011) due to the rapid accumulation of VFA from uncoupling between the acid producers and consumers. The consequences of the AD process imbalance are financial losses due to reduced biogas yield and increased staff deployment and chemical addition cost. Therefore, it is necessary to solve these problems on time.

The typical recovery strategy for the AD process imbalance is stopped feeding to restore the ecological function of microorganisms in the AD system via self-recovery. However, this strategy requires a long time and is not economically feasible. The stop feeding strategy, combined with the addition of trace elements, could accelerate the recovery process of the inhibited AD reactor but still requires a long stop feeding period (Voelklein et al., 2017). The 
91 recovery of VFA and low $\mathrm{pH}$ inhibition in real-time without stop feeding is still a significant 92 challenge. Adjusting the $\mathrm{pH}$ of the inhibited $\mathrm{AD}$ reactor to near-neutral was often applied to 93 enhance the buffering capacity of the AD system against VFA disturbance, with low cost and 94 smooth operation. The adjusted $\mathrm{pH}$ in the AD reactor could recover the AD process from low $\mathrm{pH}$ 95 inhibition with a stable operation (Zhang et al., 2013). Alkaline addition to the AD reactor 96 improved the buffering capacity to meet the requirements of the microbial populations (Zhang et 97 al., 2016) and enhance activities of the acidogenic bacteria and methanogenic archaea (Zhang et 98 al., 2012). Alkaline substances, such as $\mathrm{Na}_{2} \mathrm{CO}_{3}$ and $\mathrm{NaHCO}_{3}$, exhibited more pronounced 99 effects on the stability of the $\mathrm{AD}$ process than $\mathrm{NaOH}$ due to $\mathrm{CO}_{3}{ }^{2-}$ and $\mathrm{HCO}_{3}{ }^{-}$having a higher

100 buffering capacity than $\mathrm{OH}^{-}$(Jun et al., 2009). Additionally, instead of alkaline chemicals, wood 101 ash was used to adjust the $\mathrm{pH}$ of the $\mathrm{AD}$ process as a cheap material alternative

102 (Saritpongteeraka \& Chaiprapat, 2008). Oil palm ash was used to adjust the pH of POME with

103 high biogas production, rather than raw POME, due to the releasing buffer capacity and 104 micronutrient (Gómez et al., 2006). However, the pH adjustment strategy could not recover the 105 imbalanced AD reactor, but only delayed the AD process failure (Gómez et al., 2006).

106 Nevertheless, the addition of fresh and active methane-producing sludge, with the addition of 107 micronutrient, has been used to recover the imbalanced AD reactor (Lee \& Shoda, 2008; Qiang 108 et al., 2013). The re-inoculation (Wu et al., 2015) or bioaugmentation (Li et al., 2018) of highactivity anaerobic microorganism was used to restart the out-of-order AD reactor, and this was

110 significantly effective in the short-term, although expensive. The combination of the $\mathrm{pH}$ 111 adjustment with trace elements and re-inoculation was always useful but costly (Zhang et al.,

112 2018). All strategies described above have proved to be effective methods to recover the 113 imbalanced AD process. However, a systematic and comprehensive evaluation of the recovery 114 strategies from the imbalanced AD reactor feed with POME has yet to be reported.

115 This work aims to recover the imbalanced AD reactor feed with POME by pH adjustment

116 with an alkaline substance, diluting the toxic compounds with tap water and biogas effluent, and

117 re-inoculation addition of active methane-producing sludge. The microbial community

118 responsible for each recovery strategy was investigated, and the knowledge from our research

119 can provide economically feasible and rapid recovery methods for imbalanced commercial 120 biogas reactors. 
122 Materials \& Methods

123 Characteristics of inhibited AD sludge, POME, biogas effluent, and active methane124 producing sludge

125

126

127

128

129

130

131

132

133

134

135

136

137

138

139

140

141

142

143

144

145

146

147

148

149

150

An inhibited sludge sample was collected from the mesophilic biogas plant $\left(40 \pm 2^{\circ} \mathrm{C}\right)$ of a palm oil mill, Prasang Green Power Co., Ltd., Surat Thani Province, Thailand. The biogas reactor was operated in continuous mode, feeding with POME at a high OLR (4.5 g-COD/L/d), resulting in acidification of the $\mathrm{AD}$ reactor. Biogas effluent, POME, and active methaneproducing sludge were collected from the biogas plant at Pitak Palm Oil Co., Ltd., Trang Province, Thailand, and analyzed for their characteristics, according to the procedure described in APHA (2012). The inhibited sludge had an acidic pH (3.9), $4.8 \mathrm{~g} / \mathrm{L}$ of total volatile fatty acids (tVFA), $17.0 \mathrm{~g} / \mathrm{L}$ of suspended solids (SS), and $14.5 \mathrm{~g} / \mathrm{L}$ of volatile suspended solids (VSS). The active methane-producing sludge had neutral $\mathrm{pH}$ (7.5), very low tVFA (0.92 g/L), but a high SS and VSS content of $59.8 \mathrm{~g} / \mathrm{L}$ and $52.2 \mathrm{~g} / \mathrm{L}$, respectively.

\section{Recovery of AD process imbalance}

Experiments carried out in a batch reactor, an AD process imbalance, indicated by inhibited sludge, were recovered using three strategies. Firstly, the inhibited sludge sample was diluted with tap water (TW) and biogas effluent (BE) at a ratio of 9:1, 8:2, 7:3, 6:4, and 5:5, respectively, as a dilution strategy. Secondly, the $\mathrm{pH}$ of inhibited sludge was adjusted using 0.85$1.50 \% \mathrm{w} / \mathrm{v}$ sodium hydrogen carbonate $\left(\mathrm{NaHCO}_{3}\right), 0.10-0.14 \% \mathrm{w} / \mathrm{v}$ sodium hydroxide $(\mathrm{NaOH})$, $0.10-0.50 \% \mathrm{w} / \mathrm{v}$ calcium hydroxide $\mathrm{Ca}(\mathrm{OH})_{2}$ and $6.0-10.0 \% \mathrm{w} / \mathrm{v}$ oil palm ash as $\mathrm{pH}$ adjustment strategy. Thirdly, the inhibited sludge was recovered by adding active methane-producing sludge at $5,10,15,20,25,30,35,40,45$, and $50 \% \mathrm{v} / \mathrm{v}$ called re-inoculation or bioaugmentation strategy. All strategies were combined with 20\% v/v POME addition as low flow rate feeding (40 $\mathrm{m}^{3}$-POME/d), instead of stop feeding, and self-recovery was used as a control. All strategies were tested at an inhibited sludge sample concentration of $1 \mathrm{~g}$ VSS. All experiments were flushed with $\mathrm{N}_{2}: \mathrm{CO}_{2}$ mixed at 80:20 ratios to create the anaerobic condition and secured tightly with a butyl-rubber septum and aluminum cap. The experiment was carried out in triplicate and at a temperature of $\left(40 \pm 2{ }^{\circ} \mathrm{C}\right)$ for 45 days. The biogas production in the headspace was measured via the water displacement method, and the biogas content was analyzed by a gas chromatograph 
151 equipped with thermal conductivity detectors (GC-TCD). Microbial sludge from each treatment

152 was analyzed for the microbial community structure using polymerase chain reaction denaturing

153 gradient gel electrophoresis (PCR-DGGE) techniques. The specific methanogenic activity

154 (SMA) of the inhibited sludge and recovery sludge was also determined (Hussain \& Dubey,

155 2017). The recovery time is the incubation time for methane production reaches $90 \%$ of

156 maximum methane production in the recovery experiment and simulation results ( $W u$ et al.,

157 2015).

158 The validity of lab-scale results in the full-scale recovery of AD process imbalance

159 The inhibited sludge from a $6,000 \mathrm{~m}^{3}$ full-scale hybrid cover lagoon reactor was tested in

160 the lab-scale experiment for recovery strategies. The selected strategy (dilution with biogas

161 effluent) was applied to a $6,000 \mathrm{~m}^{3}$ full-scale hybrid cover lagoon reactor (Prasang Green Power

162 Co., Ltd., Surat Thani Province, Thailand) for recovery of the AD process imbalance and

163 validated the lab-scale results. The biogas reactor was operated at hydraulic retention times

164 (HRT) of 30 days. The organic loading rate (OLR) was reduced from $4.5 \mathrm{~kg} \mathrm{COD} / \mathrm{m}^{3} / \mathrm{d}$ to 1.25

$165 \mathrm{~kg} \mathrm{COD} / \mathrm{m}^{3} / \mathrm{d}$. The $50 \mathrm{~m}^{3}$ of inhibited sludge and $10 \mathrm{~m}^{3}$ of POME were diluted with biogas

166 effluent at a ratio of 8:2 every day for two weeks before adding to the full-scale hybrid cover

167 lagoon reactor. The reactor was operated normally when the $\mathrm{pH}$ of inhibited sludge was

168 increased to 7.5. Biogas effluent with $\mathrm{pH} 7.8$ was collected from another biogas reactor effluent

169 with good performance at Prasang Green Power Co., Ltd., Surat Thani Province, Thailand.

170 POME was collected from the palm oil mill at the biogas plant at Prasang Green Power Co.,

171 Ltd., Surat Thani Province, Thailand. The $\mathrm{pH}$ and methane production rate of full-scale biogas

172 sludge were monitored daily. The SMA of full-scale biogas sludge was monitored every 3 days.

173 Acetate was used as a substrate during SMA tests as representative acetoclastic bacteria to

174 investigate the reactor performance during the recovery process.

\section{Microbial activity and microbial community analysis}

The inhibited and recovered sludge methanogenic activities were evaluated by the SMA

177 test using avicel (cellulose), glucose, gelatin, and acetic acid as a representative microbial

178 population group of hydrolytic bacteria, acidogenic bacteria, proteolytic bacteria and,

179 methanogenic archaea, respectively. This evaluates the anaerobic sludge capability to convert an 
180 organic substrate into methane, escaping quickly to the gas phase, reducing the COD in a liquid

181 phase. The SMA value was calculated by the slope of methane production (based on $\mathrm{g}$ COD of

$182 \mathrm{CH}_{4}$ ) against incubation time and divided with VSS added of sludge sample (Hussain \& Dubey,

183 2017). The microbial community structure was analyzed by polymerase chain reaction

184 denaturing gradient gel electrophoresis (PCR-DGGE) techniques, according to Prasertsan et al.

185 (2009). The $0.2 \mathrm{~g}$ of the sludge sample was extracted for genomic DNA using the Ultraclean Soil

186 DNA Kit (MoBio Laboratory Inc., USA). The 16S rDNA gene of bacteria was amplified by the

187 first PCR with universal primer 27f (GAGTTTGATCCTTGGCTCAG) and 1525r

188 (AAGGAGGTGWTCCARCC). 16S rDNA gene for archaea was amplified using Arch21f

189 primers (TTCCGGGTTGATCCYGCCGGA) and Arch958r (YCCGGCGTTGAMTCCAATT).

190 The V3 region of bacteria was amplified in a second PCR by primer $357 \mathrm{f}$

191 (CTCCTACGGGAGGCAGCAG) with CG clamp and 518r (GTATTACCGCGGCTGCTGG),

192 using the first bacteria PCR as a template. The V3 region of archaea was amplified in a second

193 PCR by primer 340f (CCTACGGG-GYGCASCAG) with CG clamp and 519r

194 (TTACCGCGGCKGCTG), using the product of first archaea PCR as a template. Second PCR

195 products performed the denaturing gradient gel electrophoresis (DGGE) analysis with 6\%

196 polyacrylamide gel for bacteria and 8\%polyacrylamide gel for archaea containing a linear of

197 urea/formamide gradient with denaturant ranging from $40 \%$ to $70 \%$ in 0.5 TAE buffer at 20 volts

198 for 20 minutes, and 70 volts for 15 hours, at a constant temperature of $60^{\circ} \mathrm{C}$. Sybr-Gold was

199 stained in the DGGE gels for 60 minutes and photographed on the Gel Doc XR system (Bio-Rad

200 Laboratories). Predominant DGGE bands were excised with a sterile tip and suspended in $30 \mu \mathrm{L}$

201 sterilized Milli-Q water. Excised DGGE band was incubated at $4^{\circ} \mathrm{C}$ overnight and re-amplified

202 by PCR using the same primers without the GC clamp. PCR products were purified and

203 sequenced by Macrogen Inc. (Seoul, South Korea). Closest matches for partial 16S rRNA gene

204 sequences were identified by database searches in Gene Bank using BLAST (Tatusova et al.,

205 2016).

206 Analytical methods and calculation

207 The biogas composition $\left(\mathrm{H}_{2}, \mathrm{~N}_{2}, \mathrm{CH}_{4}\right.$, and $\left.\mathrm{CO}_{2}\right)$ was determined by gas chromatograph

208 GC-8A (Shimadzu, Kyoto, Japan) with a 1-meter stainless steel column packed with Shin

209 Carbon (60/80 mesh) equipped with thermal conductivity detectors (TCD). The argon at a flow 
210 rate of $14 \mathrm{~mL} / \mathrm{min}$ was used as the carrier gas. The temperatures of the oven, detector, and 211 injection port were at $40{ }^{\circ} \mathrm{C}, 100^{\circ} \mathrm{C}$, and $120^{\circ} \mathrm{C}$, respectively. The $0.5 \mathrm{~mL}$ of the biogas sample

212 was injected in duplicate for each reactor. The daily biogas production for each reactor was 213 counted using the water displacement method (Yan et al., 2015). The chemical and physical 214 composition of POME, biogas effluent, active methane-producing sludge, and inhibited sludge

215 were determined for $\mathrm{pH}$, lipid content, total solids (TS), volatile solids (VS), volatile suspended 216 solids (VSS), total nitrogen (TN), total volatile fatty acid (tVFA), and alkalinity according to 217 Standard Methods for the Examination of Water and Wastewater (APHA, 2012). Determination 218 of TS was performed at a temperature of $90^{\circ} \mathrm{C}$ instead of $105^{\circ} \mathrm{C}$, till constant weight to avoid 219 decreasing of VFAs (Angelidaki et al., 2009). The VFAs composition was determined through a 220 gas chromatograph GC-17A (Shimadzu, Kyoto, Japan) with a Stabilwax ${ }^{\circledR}-D A$ fused silica 221 column $\left(30 \mathrm{~m}\right.$ of length, $0.53 \mathrm{~mm}$ of diameter, $85^{\circ} \mathrm{C}$ ) connected to a flame ionization detector 222 (FID) at $240^{\circ} \mathrm{C}$. The helium at $30 \mathrm{~mL} / \mathrm{min}$ was used as the carrier gas. The VFA samples were 223 collected by syringe $(1 \mathrm{~mL})$ and filtered through a nylon membrane $(0.2 \mu \mathrm{m})$. The filtrated 224 samples were acidified to $\mathrm{pH}$ 3.0-3.2 with 30\% (v/v) phosphoric acid for VFAs analysis (Raposo 225 et al., 2015). Buswell's equation was used to calculate theoretical methane yield, assuming the 226 total stoichiometry conversion of the organic matter to methane and carbon dioxide (Buswell \& 227 Mueller, 1952). The hydrolysis constants $\left(\mathrm{k}_{\mathrm{H}}\right)$ were determined by using the first-order kinetic 228 model in equation (1) according to the protocol of Raposo et al. (2006). Where B ( $t$ ) is the 229 cumulative methane yield ( $\left.\mathrm{mL}-\mathrm{CH}_{4} / \mathrm{g}-\mathrm{VS}_{\text {added }}\right)$ at time $\mathrm{t}$, and $\mathrm{B}_{\infty}$ is the maximum cumulative 230 methane yield ( $\left.\mathrm{mL}-\mathrm{CH}_{4} / \mathrm{g}-\mathrm{VS}_{\mathrm{added}}\right) . \mathrm{k}_{\mathrm{H}}$ is the hydrolysis constant $\left(\mathrm{d}^{-1}\right) ; \mathrm{t}$ is the fermentation time; $231 \lambda$ is the lag phase (day).

232

$233 \mathrm{~B}(\mathrm{t})=\mathrm{B}_{\infty}\left[1-\exp \left(-\mathrm{k}_{\mathrm{H}}(\mathrm{t}-\lambda)\right)\right]$

234

235 The modified Gompertz model was used to predict the methane production, methane production 236 rate, and lag phase (Nopharatana et al., 2007) as follows in equation (2).

237

$238 \mathrm{M}=\mathrm{P} \cdot \exp \left\{-\exp \left[\frac{\mathrm{Rm} \mathrm{e}}{\mathrm{P}}(\lambda-\mathrm{t})+1\right]\right\}$ 
Where $\mathrm{M}$ is the cumulative methane yield at the time $\mathrm{t}\left(\mathrm{mL}-\mathrm{CH}_{4} / \mathrm{g}-\mathrm{VS}\right.$ added $)$; is the

241 maximum cumulative methane yield ( $\left.\mathrm{mL}-\mathrm{CH}_{4} / \mathrm{g}-\mathrm{VS}_{\mathrm{added}}\right) ; \mathrm{Rm}$ is the maximum methane

242 production rate $\left(\mathrm{mL}-\mathrm{CH}_{4} / \mathrm{g}-\mathrm{VS} / \mathrm{d}\right) ; \lambda$ is the lag phase $(\mathrm{d}) ; \mathrm{t}$ is the fermentation time, and e is the

243 Euler constant (2.718282). The economic evaluation of each recovery strategy was calculated

244 from the chemical addition cost, human resources, energy consumption, biogas loss, and biogas

245 production during the recovery period according to the current market price and the average

246 price of industrial water in Thailand. Biogas price is $0.21 \mathrm{USD} / \mathrm{m}^{3}$. The cost of $\mathrm{NaOH}, \mathrm{Ca}(\mathrm{OH})_{2}$,

247 and $\mathrm{NaHCO}_{3}$ was $0.35,0.2$, and $0.3 \mathrm{USD} / \mathrm{kg}$, respectively. The cost of human resources was 10

$248 \mathrm{USD} /$ people/d. The cost of electricity consumption was $0.13 \mathrm{USD} / \mathrm{kWh}$. Biogas loss is the

249 average daily biogas during a good performance period $\left(3,000 \mathrm{~m}^{3} / \mathrm{d}\right)$ minus biogas production

250 during the recovery period.

\section{Results}

\section{Recovery of AD process imbalance}

253

254

255

256

257

258

259

260

261

262

263

264

265

266

267

268

269

The AD process imbalance is caused by a low $\mathrm{pH}$ and high VFAs accumulation due to organic overload and low degradation efficiency. Inhibited sludge had low pH (3.9) and a high total VFA (4.8 g/L) with butyric acid $(2.5 \mathrm{~g} / \mathrm{L})$ and acetic acid $(1.8 \mathrm{~g} / \mathrm{L})$ as the main VFA (Table 1). It also had a low SS and VSS of $14.5 \mathrm{~g} / \mathrm{L}$ and $11.0 \mathrm{~g} / \mathrm{L}$, respectively, indicating a low number of anaerobic microorganisms in the systems. The specific methanogenic activity (SMA) of the inhibited sludge with glucose, acetic acid, avicel (cellulose), and gelatin was 0.208, 0.344, 0.401, and $0.065 \mathrm{gCH}_{4}-\mathrm{COD} / \mathrm{gVSS} / \mathrm{d}$, respectively (Fig. 1). The SMA of acetic acid $\left(0.344{\mathrm{~g}-\mathrm{CH}_{4}-}^{-}\right.$ $\mathrm{COD} / \mathrm{g}-\mathrm{VSS} / \mathrm{d}$ ) was lower than the SMA of avicel (cellulose), indicating a low number of methanogenic archaea for reducing acetate to $\mathrm{CH}_{4}$ and $\mathrm{CO}_{2}$ but a high number of hydrolytic bacteria and acidogenic bacteria for acid production. The $\mathrm{pH}$ of inhibited sludge was gradually increased from 5.7 to 7.8. Data files regarding SMA analysis of inhibited microbial sludge, selfrecovery sludge, and all recovered strategy were showed in Data $\mathrm{S} 1$. The acidic $\mathrm{pH}$ directly affected microbial activity, leading to a low methane production rate $\left(40.8 \mathrm{~mL}-\mathrm{CH}_{4} / \mathrm{d}\right)$ and extended recovery time (49.4 days). The self-recovery had low hydrolysis constant $\left(k_{H}\right)\left(0.005 \mathrm{~d}^{-}\right.$ 1) with a long lag phase (21.2 days) and low methane yield (209 $\left.\mathrm{mL}-\mathrm{CH}_{4} / \mathrm{g}-\mathrm{VS}_{\mathrm{added}}\right)$ were observed in self-recovery (Table 2). The specific methanogenic activity of self-recovery was lower than those of the inhibited sludge for cellulose and glucose as substrate $(0.112$ and 0.106 
$270 \mathrm{gCH}_{4}-\mathrm{COD} / \mathrm{gVSS} / \mathrm{d}$, respectively) but higher for acetic acids and gelatin substrate ( 0.481 and $2710.122 \mathrm{gCH}_{4}-\mathrm{COD} / \mathrm{gVSS} / \mathrm{d}$, respectively) (Fig. 1). The SMA test using avicel (cellulose), glucose, 272 gelatin, and acetic acid as a substrate is a representative microbial population group of hydrolytic 273 bacteria, acidogenic bacteria proteolytic bacteria, and methanogenic archaea, respectively.

274 Methane production was achieved from self-recovery but the low activity of specific

275 methanogenic activity, indicating low active methane-producing microorganisms in the self276 recovery strategy. A more detailed biogas production data of each recovery strategy and self277 recovery will be provided in Data S2.

278 The recovery by dilution strategy with biogas effluent (BE) gave higher methane yield

279 (214-282 $\mathrm{mL}-\mathrm{CH}_{4} / \mathrm{g}-\mathrm{VS}_{\text {added }}$ ) and methane production rate $\left(53.4-108.0 \mathrm{~mL}-\mathrm{CH}_{4} / \mathrm{d}\right)$ than the 280 recovery by dilution with tap water (TW) $\left(177-190 \mathrm{~mL}^{-\mathrm{CH}_{4}} / \mathrm{g}-\mathrm{VS}_{\text {added }}\right.$ and $40.7-62.5 \mathrm{~mL}-\mathrm{CH}_{4} / \mathrm{d}$, 281 respectively) and the self-recovery (Table 2). The lag phase of recovery by dilution with BE 282 (7.1-12.3 days) and dilution with TW (9.9-15.1 days) were significantly shorter than self283 recovery (21.2 days). The recovery time of dilution with TW and BE was in the same range 284 (33.2-41.7 days and 32.8-42.0 days, respectively). The dilution with TW could reduce toxicity in 285 the inhibited sludge so that lag phase and recovery time could be decreased, but not enhanced 286 methane-producing microorganisms resulting in low methane yield and methane production rate. 287 The recovery by dilution with BE at a ratio of $8: 2$ to $5: 5$ had a $20-32 \%$ shorter lag phase and 288 recovery time than the self-recovery. The recovery by dilution with BE could enhance active 289 methane-producing microorganisms in sludge and resulted in a 2.2 fold increase of the methane 290 production rate (91.4-92.8 $\mathrm{mL}-\mathrm{CH}_{4} / \mathrm{d}$ compared to $40.8 \mathrm{~mL}^{-\mathrm{CH}_{4}} / \mathrm{d}$, respectively). The recovery 291 by dilution with BE had specific methanogenic activity higher than self-recovery. The specific 292 methanogenic activity of recovery sludge with glucose, acetic acid, cellulose, and gelatin was $2930.234,0.684,0.528$, and $0.134 \mathrm{gCH}_{4}-\mathrm{COD} / \mathrm{gVSS} / \mathrm{d}$, respectively. The methane yield of dilution 294 with BE strategy was 34.9\% higher than the self-recovery and showed better growth of 295 methanogens under suitable $\mathrm{pH}$ (6.5-7.3). Therefore, the dilution of the inhibited sludge with BE 296 at a ratio of 8:2 was a suitable strategy to accelerate the recovery process of the sludge from the 297 inhibited state.

298 The recovery by adjusting $\mathrm{pH}$ strategy with all concentrations tested of $(0.10-0.5 \% \mathrm{w} / \mathrm{v})$ $299 \mathrm{Ca}(\mathrm{OH})_{2},(0.10-0.14 \% \mathrm{w} / \mathrm{v}) \mathrm{NaOH},(6.00-10.00 \% \mathrm{w} / \mathrm{v})$ oil palm ash, except $(0.85-1.25 \% \mathrm{w} / \mathrm{v}$ $300 \mathrm{NaHCO}_{3}$ ) exhibited higher methane yield and methane production rate than the self-recovery 
301 (Table 2). The highest methane yield (383 $\left.\mathrm{mL}-\mathrm{CH}_{4} / \mathrm{g}-\mathrm{VS}_{\text {added }}\right)$ was achieved from the recovery

302 by adjusting $\mathrm{pH}$ with $0.14 \% \mathrm{w} / \mathrm{v} \mathrm{NaOH}$ with the methane production rate of $111.7 \mathrm{~mL}-\mathrm{CH}_{4} / \mathrm{d}$.

303 On the other hand, the highest methane production rate $\left(226.3 \mathrm{~mL}_{-} \mathrm{CH}_{4} / \mathrm{d}\right)$ was achieved from the

304 recovery by adjusting $\mathrm{pH}$ with $8.0 \% \mathrm{w} / \mathrm{v}$ oil palm ash with the hydrolysis constant $\left(k_{H}\right)$ of 0.007

$305 \mathrm{~d}^{-1}$ and lag phase of 8.2 days with the recovery time of 32.4 days. In terms of the specific SMA

306 of recovery sludge by three alkaline sources for adjusting $\mathrm{pH}, \mathrm{Ca}(\mathrm{OH})_{2}$ showed the highest SMA

307 on acetic acid and cellulose, as substrates were 0.767 and $0.821 \mathrm{gCH}_{4}-\mathrm{COD} / \mathrm{gVSS} / \mathrm{d}$,

308 respectively. In contrast, the highest SMA on glucose and gelatin $\left(0.591\right.$ and $0.096 \mathrm{gCH}_{4}-$

$309 \mathrm{COD} / \mathrm{gVSS} / \mathrm{d}$, respectively) were obtained from recovery by adjusting $\mathrm{pH}$ with $8.00 \% \mathrm{w} / \mathrm{v}$ oil

310 palm ash. Thus, the $\mathrm{pH}$ adjustment strategy using $0.14 \% \mathrm{w} / \mathrm{v} \mathrm{NaOH}$ and $0.40 \% \mathrm{w} / \mathrm{v} \mathrm{Ca}(\mathrm{OH})_{2}$

311 gave the highest methane yields of 383 and $373 \mathrm{~mL}-\mathrm{CH}_{4} / \mathrm{g} . \mathrm{VS}_{\text {added }}$, respectively, while using

$3128.00 \% \mathrm{w} / \mathrm{v}$ oil palm ash and $0.40 \% \mathrm{w} / \mathrm{v} \mathrm{Ca}(\mathrm{OH})_{2}$ gave the highest methane production rates of

313226.3 and $151.4 \mathrm{~mL}-\mathrm{CH}_{4} / \mathrm{d}$, respectively. The $0.40 \% \mathrm{w} / \mathrm{v} \mathrm{Ca}(\mathrm{OH})_{2}$ was demonstrated effective in

314 accelerating recovery of the inhibited sludge by saving $31.6 \%$ recovery time (from 49.4 days to

31533.8 days) and enhancing the methane yield of $78.5 \%$ (from 209 to $373 \mathrm{~mL}-\mathrm{CH}_{4} / \mathrm{g}$. VS $\mathrm{S}_{\text {added }}$ ) when

316 compared with self-recovery. Nevertheless, the $\mathrm{pH}$ adjustment strategy from the best results of

317 each source of alkaline $\left(0.14 \% \mathrm{w} / \mathrm{v} \mathrm{NaOH}, 0.40 \% \mathrm{w} / \mathrm{v} \mathrm{Ca}(\mathrm{OH})_{2}, 1.25 \% \mathrm{w} / \mathrm{v} \mathrm{NaHCO}_{3}\right.$, and

$3188.00 \% \mathrm{w} / \mathrm{v}$ oil palm ash) was selected for economic evaluation compared to the dilution strategy

319 (dilution with $\mathrm{BE}$ at 8:2 ratio).

320 The recovery by bioaugmentation or re-inoculation of active methane-producing sludge

321 at 5-50\% into the inhibited sludge was able to accelerate the recovery process in terms of

322 methane yield (212-237 $\left.\mathrm{mL}^{-\mathrm{CH}_{4}} / \mathrm{g}-\mathrm{VS}_{\text {added }}\right)$, methane production rate (40.4-83.5 mL-CH4/d), lag

323 phase (15.2-11.0 days) but not reduced the recovery time (43.6-47.2 days) (Table 3). Its $k_{H}$ value

324 was $0.006-0.008 \mathrm{~d}^{-1}$. The addition of active methane-producing sludge at $15-50 \%$ had a methane

325 production rate higher than the self-recovery because it can improve the amount of active

326 biomass. The recovery of this strategy gave a small improvement with a long recovery time of

32745.8 days and not difference with self- recovery (49.20 days). In particular, $k_{H}$ of the addition of

328 active methane-producing sludge strategy was small increased when compared with self-

329 recovery. The amount of active methane-producing sludge at 30\%-50\% was suitable for recovery

330 of the inhibited sludge with a shorter lag phase and increased tolerance of microorganism to low 
$331 \mathrm{pH}$ and high VFAs. However, the addition of active methane-producing sludge strategy had

332 lower recovery efficiency than alkali addition due to low buffering capacity.

333 Economic evaluation

334 The energy and economic evaluation of each recovery strategy were provided in this

335 study. The price of chemical addition, energy consumption, biogas loss, and human resources

336 was achieved according to the current market price and the average price of industrial water in

337 Thailand. According to Table 4, there were no extra-economic benefits from either of the

338 recovery strategies. The recovery by $\mathrm{NaOH}$ addition, dilution with biogas effluent, and oil palm

339 ash addition could reduce the recovery cost of the inhibited AD systems more than other

340 strategies. The net profit of strategies for recovery inhibited sludge is in the following order

341 (USD $\left./ \mathrm{m}^{3} / \mathrm{d}\right): \mathrm{NaOH}$ addition (-1.76), dilution with biogas effluent (-1.77), oil palm ash addition

$342(-1.79) \mathrm{Ca}(\mathrm{OH})_{2}$ addition (-2.49), dilution with tap water (-3.33), and $\mathrm{NaHCO}_{3}$ addition (-7.2).

343 The recovery by $0.14 \% \mathrm{w} / \mathrm{v} \mathrm{NaOH}$ addition corresponding to the addition of $\mathrm{NaOH}$ of 1.40

$344 \mathrm{~kg} / \mathrm{m}^{3}$-inhibited sludge had the chemical addition cost of $0.49 \mathrm{USD} / \mathrm{m}^{3} / \mathrm{d}$. The recovery by

345 dilution with biogas effluent at a ratio of $8: 2$ corresponding to $0.2 \mathrm{~m}^{3} / \mathrm{m}^{3}$-inhibited had no cost

346 for biogas effluent. The recovery by $8.00 \% \mathrm{w} / \mathrm{v}$ of oil palm ash addition corresponding oil palm

347 ash of $80 \mathrm{~kg} / \mathrm{m}^{3}$-inhibited sludge had no oil palm ash cost. Oil palm ash is a by-product obtained

348 by burning fibers, shells, and empty fruit bunches as fuel in palm oil mill boilers, while biogas

349 effluent is that from $\mathrm{AD}$ digester free of charge. Thus, we suggest that $\mathrm{NaOH}$ addition, dilution

350 with biogas effluent, and oil palm ash addition could be economically feasible strategies to

351 recover the inhibited AD system feeding with POME.

352 The validity of lab-scale results in the full-scale recovery of AD process imbalance

353 Full-scale recovery was conducted by diluting $50 \mathrm{~m}^{3}$ of inhibited sludge with biogas

354 effluent at a ratio of $8: 2$, which was added to $6,000 \mathrm{~m}^{3}$ biogas reactors every day. The AD

355 imbalance reactor was maintained by a low feeding rate of $10 \mathrm{~m}^{3}-\mathrm{POME} / \mathrm{d}$. After dilution, the

$356 \mathrm{pH}$ increased from 5.6 to 6.8 in the first week and 7.8 in the second week. After that, the reactor

357 was operated normally with a feeding rate of $200 \mathrm{~m}^{3}-\mathrm{POME} / \mathrm{d}$. The methane production rates of

358 the first, second, and third weeks of dilution with biogas effluent were $0.8,2.0$, and $2.86 \mathrm{~m}^{3}$ -

$359 \mathrm{CH}_{4} / \mathrm{m}^{3}$-reactor /d with the $\mathrm{pH}$ values of $6.8,7.8$, and 7.8, respectively (Fig. 2). The SMA values 
360 of the first, second, and third weeks of dilution with biogas effluent were also increased to 0.44 , 3610.70 , and $0.71 \mathrm{~g}-\mathrm{CH}_{4}-\mathrm{COD} / \mathrm{g}-\mathrm{VSS} / \mathrm{d}$, respectively. Results indicated that the reactor recovered

362 within two weeks after dilution with biogas effluent. Therefore, this recovery time (15 days)

363 gave a better result than lab-scale reactor (36.4 days).

364 Microbial community responsible for high potential recovery strategies

365

366

367

368

369

370

371

372

373

374

375

376

377

378

379

380

381

382

383

384

385

386

387

388

389

The microbial community from the four high potential recovery strategies (dilution with $\mathrm{BE}$ at a ratio of $8: 2,0.14 \% \mathrm{w} / \mathrm{v} \mathrm{NaOH}$ addition, $0.50 \% \mathrm{w} / \mathrm{v} \mathrm{Ca}(\mathrm{OH})_{2}$ addition, and $8.00 \% \mathrm{w} / \mathrm{v}$ oil palm ash addition) indicated by short time lag phase, short recovery time, high SMA activity, and high methane production was analyzed. The heat map of the bacterial and archaeal communities of these four recovered sludge were higher than those of self-recovery (Fig. 3). The bacterial community of self-recovery strategy was dominated by Desulfotomaculum sp., Bacteroidetes sp., and Lactobacillus sp. (Fig. 3A). The number of Clostridium sp., Anaerostipes sp., Lynsinibacillus sp. increased after 12 days of self-recovery. For the archaea community, selfrecovery was dominated by Methanosaeta sp. (Fig. 3B). The numbers of Methanosaeta sp. and Methanosarcina sp. increased after 12 days of self-recovery, while the bacteria in recovery by dilution with BE, at a ratio of 8:2, was dominated by Desulfotomaculum sp., Lactobacillus sp., Bacteroidetes sp., Clostridium sp., Staphylococcus sp., Selenomonas sp., and Lynsinibacillus sp., in which the last four species increased after 5 days of recovery. The archaea community was dominated by Methanosaeta sp. and Methanosarcina sp. in which the latter species decreased after 5 days of recovery. The recovery by $0.14 \% \mathrm{w} / \mathrm{v} \mathrm{NaOH}$ addition was dominated by Desulfotomaculum sp., Blautia sp., Lactobacillus sp., Bacteroidetes sp., and Selenomonas sp., with the number of Blautia sp., Clostridium sp., Anaerostipes sp., Lynsinibacillus sp., and Staphylococcus sp. increasing after 5 days of recovery. Furthermore, the archaeal community was dominated by Methanosaeta sp., Methanosarcina sp., and Methanococcoides sp. after 5 days of recovery. The recovery by $0.50 \% \mathrm{w} / \mathrm{v} \mathrm{Ca}(\mathrm{OH})_{2}$ addition was dominated by Desulfotomaculum sp., Blautia sp., Clostridium sp., Anaerostipes sp., Kurthia sp., Exiguobacterium sp., Staphylococcus sp., Selenomonas sp., Bacillus sp., Lynsinibacillus sp., Lactobacillus sp., and Bacteroidetes sp., in which the last two species did not appear at 5 days of recovery. The archaea community was dominated by Methanosaeta sp., with Methanosarcina sp., and Methanococcoides sp. at 5 days of recovery. The recovery by $8.0 \% \mathrm{w} / \mathrm{v}$ oil palm ash

Peer] reviewing PDF | (2019:10:42361:2:0:NEW 5 Nov 2020) 
390 addition was dominated by Desulfotomaculum sp., Blautia sp., Lactobacillus sp., Bacteroidetes

391 sp., Clostridium sp., Anaerostipes sp., Kurthia sp., Exiguobacterium sp., Staphylococcus sp.,

392 Selenomonas sp., Bacillus sp., and Lynsinibacillus sp., where the first four species did not appear

393 at 5 days of recovery, while the dominated archaea community is similar with the recovery by

$3940.50 \% \mathrm{w} / \mathrm{v} \mathrm{Ca}(\mathrm{OH})_{2}$. The orders Clostridiales and Bacilli were observed as main bacteria in all

395 recovered sludge. Desulfotomaculum sp. was found in all recovered strategies while Blautia sp.,

396 Clostridium sp., and Anaerostipes sp. were remarkably abundant during 12-20 days in pH

397 adjustment with $0.50 \% \mathrm{w} / \mathrm{v}$ of $\mathrm{Ca}(\mathrm{OH})_{2}$ and $8.0 \% \mathrm{w} / \mathrm{v}$ of oil palm ash addition. During the third

398 week, Bacillus sp., Lactobacillus sp., Staphylococcus sp., Kurthia sp., Lysinibacillus sp.,

399 Exiguobacterium sp., and Bacillus sp. were observed in all strategies. The recovery by $0.50 \%$

$400 \mathrm{w} / \mathrm{v} \mathrm{Ca}\left(\mathrm{OH}_{2}\right)$ and $8.00 \% \mathrm{w} / \mathrm{v}$ oil palm ash addition was predominant with bacteria belonging to

401 Kurthia sp., Exiguobacterium sp., and Bacillus sp. These bacteria can produce VFA from

402 monomers after hydrolysis, especially Exiguobacterium sp., which was a high number in the

403 third week. The member of Bacteroides sp., and Selenomonas sp. had a low number in self-

404 recovery but abundant in the recovered sludge with $0.14 \%$ of $\mathrm{NaOH}, 0.50 \%$ of $\mathrm{Ca}(\mathrm{OH})_{2}$, and

$4058.00 \%$ of oil palm ash addition. The distribution of the exclusive bacteria in different groups

406 clearly showed that the recovery strategy significantly influences the bacterial community

407 structure and selectively enriches specific acidogenic bacteria during the recovery process. The

408 acetoclastic methanogen (Methanosaeta sp.) was more abundant than hydrogenotrophic

409 methanogens in the recovered sludge. Methanosaeta sp. and Methanosarcina sp. were

410 predominant in the recovered sludge with $0.50 \% \mathrm{w} / \mathrm{v} \mathrm{Ca}(\mathrm{OH})_{2}$ and $8.00 \% \mathrm{w} / \mathrm{v}$ oil palm ash

411 addition. Molecular identification of bacteria and archaea from recovery strategy by dilution with

$412 \mathrm{BE} 8: 2$, addition with $0.14 \% \mathrm{w} / \mathrm{v} \mathrm{NaOH}, 0.50 \% \mathrm{w} / \mathrm{v} \mathrm{Ca}(\mathrm{OH})_{2}, 8.00 \% \mathrm{w} / \mathrm{v}$ oil palm ash and self-

413 recovery by denaturing gradient gel will be offered in Table S1 and Table S2, respectively).

\section{Discussion}

415 The inhibited AD sludge was caused by low $\mathrm{pH}$ and high VFA accumulation, resulting

416 in extreme alkalinity consumption from the $\mathrm{AD}$ reactor. The $\mathrm{pH}$ inside the reactor directly

417 affected the microbial activity leading to low biodegradability and methane production. The long

418 lag phase of self-recovery indicated that adaptation and initiating bacterial multiplication are

419 required due to the loss of a dynamic balance between acidogens and methanogens. Methane 
420 production was observed in self-recovery under low initial $\mathrm{pH}$ of 5.7. Several hydrogenotrophic 421 methanogens can grow and metabolize at acidic $\mathrm{pH}$ (often less than 6.0) (Charalambous et al., 422 2020). The prevalence of hydrogenotrophic methanogens over acetoclastic methanogens was 423 also reported by Kim et al. (2004) during the bioreactor operation for hydrogen production at $\mathrm{pH}$ 424 below 5.0. The dilution with tap water was not significant to accelerate the recovery of the 425 inhibited sludge. This strategy can dilute inhibitors and the active microbes and substrates, 426 resulting in a reduced methane production rate and providing long-time recovery. The dilution 427 with water at the ratio of 5:5 achieved a shorter lag time (9.1 days) than self-recovery (21.2 days) 428 but did not accelerate the recovery process (Wu et al., 2015). The dilution with BE at a ratio of $4298: 2$ could enhance methane yield of $34.7 \%$ comparing with self-recovery with shorter recovery 430 time and high $k_{H}$. The high $k_{H}$ indicates a high conversion rate of the recovered sludge

431 (Sosnowski et al., 2008). The recirculation of BE to adjust the $\mathrm{pH}$ of POME could enhance 432 methane production by two-stage anaerobic digestion with the highly flavored activity of 433 acidogens (O-Thong et al., 2016).

434 The inhibited sludge was recovered by providing alkalinity sources for methane435 producing bacteria (Chen et al., 2015). It was reported that increased alkalinity resulted in higher 436 methane production than non-alkalinity addition reactors (Lens et al., 2003). A significant 437 increase in methane production (3.03\%) was observed in the $\mathrm{AD}$ of wet poultry with $\mathrm{NaOH}$ 438 addition (Ajiboye et al., 2018). The adjusting $\mathrm{pH}$ with $0.14 \% \mathrm{w} / \mathrm{v} \mathrm{NaOH}$ addition could adjust 439 the $\mathrm{pH}$ of the inhibited sludge to $\mathrm{pH} 7.30$. The recovered sludge was a relatively stable $\mathrm{pH}$ of $4406.80-7.50$, enhancing the methane yield of $83.3 \%$ compared with self-recovery. The results 441 agreed with Zhang et al. (2018), who reported that the $\mathrm{pH}$ adjustment of the AD system by $442 \quad 0.013 \%$ of $\mathrm{NaOH}$ addition could delay the time of process failure by enhancing the tolerance of 443 methanogens to the high concentration of VFA via reducing the ratio of un-dissociated VFA.

$444 \mathrm{NaOH}$ is one of the most popular alkaline chemicals used in the AD system due to the potential 445 to buffer the $\mathrm{pH}$ (Gáspár et al., 2007). The recovery by $\mathrm{Ca}(\mathrm{OH})_{2}$ addition for adjusting the $\mathrm{pH}$ 446 of inhibited sludge showed high function as a buffering capacity for the AD system with a stable $447 \mathrm{pH}$ in the recovered AD systems. In addition, Li et al. (2009) reported the $\mathrm{pH}$ adjustment with $448 \mathrm{Ca}(\mathrm{OH})_{2}$ improved the methanogenic activity by maintaining a stable $\mathrm{pH}$ for methanogens. The $449 \mathrm{Ca}(\mathrm{OH})_{2}$ addition at a concentration of $0.6 \% \mathrm{w} / \mathrm{v}$ to $1.0 \% \mathrm{w} / \mathrm{v}$ could maintain active methane450 producing microorganisms and stability in the AD process (Zhang et al., 2014). However, the 
451 accumulation of $\mathrm{Ca}^{2+}$ may lead to the precipitation of calcium salt and accumulation on the 452 reactor walls leading to loss of nutrition and lower buffer ability in the AD system (Zhu et al., 453 2010). The recovery by oil palm ash addition can improve the buffer capacity and methane 454 production rate of the inhibited sludge with a short lag phase and short recovery time. The 455 addition of ash could increase functional buffering capacity corresponding with Bunrung et al. 456 (2011), who reported that $15 \%(\mathrm{w} / \mathrm{v})$ oil palm ash addition resulted in increased $\mathrm{pH}$ from 7.5 to 457 9.1. Oil palm ash composed of silicon dioxide (58-65\%), calcium oxide (6-7\%), and potassium 458 oxide (7-8\%) could improve buffer capacity and $\mathrm{pH}$ of the AD systems in the range of 8.25-9.14 459 (Tangchirapat et al., 2009). The oil palm ash addition of 1.18\% w/v into POME improved 460 methane yield ( $218.79 \mathrm{~mL}^{-\mathrm{CH}_{4}} / \mathrm{g}-\mathrm{COD}$ ) and adjusted the $\mathrm{pH}$ in the suitable range for AD 461 systems (Jijai et al., 2017). The recovery by $\mathrm{NaHCO}_{3}$ addition had low recovery efficiency due 462 to $\mathrm{Na}^{+}$at high concentration could inhibit the methanogens resulting in a low methane production 463 rate (Zhang et al. 2016). The $\mathrm{Na}^{+}$slightly inhibited the methanogens in AD systems at $0.31 \%$ 464 w/v of $\mathrm{NaHCO}_{3}$ addition (Chen et al., 2008). The recovery by the addition of active methane465 producing sludge can reduce the lag phase with the small improvement of biogas production 466 comparing to self-recovery. The results in line with previous research (Salminen \& Rintala, 467 2002; Cirne et al., 2007) that an increase of active methane-producing sludge proportion can 468 reduce the recovery time from 45 to 28 days. Previous reports also showed that a re-inoculum 469 size of $80 \%$ could recover the inhibition of mesophilic anaerobic sludge treating the de-oiled grease trap waste (Wu et al., 2015).

The high recovery efficiency strategies $\left(0.50 \% \mathrm{w} / \mathrm{v} \mathrm{Ca}(\mathrm{OH})_{2}\right.$ addition $)$, dilution with 472 biogas effluent at a ratio of 8:2, and $8.00 \% \mathrm{w} / \mathrm{v}$ oil palm ash) were dominated Clostridium sp., 473 Kurthia sp., Exiguobacterium sp., Bacteroides sp., and Bacillus sp. They had been identified as 474 being involved in biogas production, especially in hydrolysis and acidogenesis stages (Wirth et 475 al., 2012). Exiguobacterium sp. has been confirmed as an amylase and protease producing 476 bacterium (Kumar et al., 2014) and produces highly effective proteolytic enzymes (Oh et al., 477 2018). The member of Bacteroides sp. has been shown as a main microbe in anaerobic reactors 478 with polysaccharide degradation (Levén et al., 2007; Trzcinski et al., 2010). Desulfotomaculum 479 sp., Blautia sp., and Clostridium sp. were fermentative bacteria and acetogenic bacteria that 480 could convert soluble organics to VFAs. The Clostridiales was generally found in the stable AD 481 digester (Li et al., 2015). The high microbial diversity in recovered sludge results in higher 
482 microbial functions with more stability in operation and good AD performances (Carballa et al., 483 2015). The acetoclastic methanogens were more abundant than hydrogenotrophic methanogens 484 in the recovered AD system. The inhibited sludge commonly induced hydrogen production and 485 consequently facilitating the growth of hydrogenotrophic methanogens (Liu et al., 2016). The 486 hydrogenotrophic methanogens were decreased in the recovered AD system. The recovery by $4870.50 \% \mathrm{w} / \mathrm{v} \mathrm{Ca}(\mathrm{OH})_{2}$ and $8.00 \% \mathrm{w} / \mathrm{v}$ oil palm ash addition enhanced acetoclastic methanogens 488 resulting in the highest methane yield and methane production rate. The dominant

489 Methanosarcina sp. was most important in the recovered AD system, which utilization acetate to 490 produce $\mathrm{CH}_{4}$. Maintenance the number of Methanosarcina sp. during the AD process is critical 491 for the stability of performance (Yang et al., 2016).

\section{Conclusions}

Recovery of the inhibited sludge by addition of $0.14 \% \mathrm{w} / \mathrm{v} \mathrm{NaOH}, 0.50 \% \mathrm{w} / \mathrm{v} \mathrm{Ca}(\mathrm{OH})_{2}$, $8.00 \% \mathrm{w} / \mathrm{v}$ oil palm ash, and dilution with biogas effluent at a ratio of 8:2 had a short lag phase with a short recovery time of 30-36 days. The dilution with biogas effluent at a ratio of 8:2, $0.14 \% \mathrm{w} / \mathrm{v} \mathrm{NaOH}$ addition, and $8.00 \% \mathrm{w} / \mathrm{v}$ oil palm ash addition was considered a more economical strategy with a recovery time of 30-36 days. The recovered AD system can increase methane yield by $35-83 \%$ and significantly higher kinetics, SMA activity, and short lag phase comparing to self-recovery. The Clostridiales sp., Bacilli sp., and Methanosarcina sp. were dominated in the recovered AD system. The imbalanced full-scale hybrid cover lagoon reactor $\left(6,000 \mathrm{~m}^{3}\right)$ was recovered within 15 days by dilution with biogas effluent at a ratio of 8:2 with a better result from the lab-scale (36.4 days).

\section{References}

Ajiboye, A. V, Lasisi, K.H., Babatola, J.O., 2018. Evaluation of the effect of sodium hydroxide solution on biogas yield of anaerobic digestion of poultry waste and the digestate. Int. J. Energy Water Resour. 2, 23-31. 
509

510

511

512

513

514

515

516

517

518

519

520

521

522

523

524

525

526

527

528

529

530

531

532

533

Anaerobic Digester. Microb. Ecol. 61, 595-605. https://doi.org/10.1007/s00248-0109788-1

Angelidaki, I., Alves, M., Bolzonella, D., Borzacconi, L., Campos, J.L., Guwy, A.J., Kalyuzhnyi, S., Jenicek, P., van Lier, J.B., 2009. Defining the biomethane potential (BMP) of solid organic wastes and energy crops: a proposed protocol for batch assays. Water Sci. Technol. 59, 927-934. https://doi.org/10.2166/wst.2009.040

APHA, AWWA, W., 2012. Standard Methods for examination of water and wastewater. 22nd ed. 5,1360 .

Ariffin, A., 2010. Production of zeolites from oil palm ash. UMP.

Bunrung, S., Prasertsan, S., Prasertsan, P., 2011. Decolourisation of biogas effluent of palm oil mill using palm ash. Parameters 4, 6.

Buswell, A.M., Mueller, H.F., 1952. Mechanism of Methane Fermentation. Ind. Eng. Chem. 44, 550-552. https://doi.org/10.1021/ie50507a033

Carballa, M., Regueiro, L., Lema, J.M., 2015. Microbial management of anaerobic digestion: exploiting the microbiome-functionality nexus. Curr. Opin. Biotechnol. 33, 103-111. https://doi.org/10.1016/J.COPBIO.2015.01.008

Chen, S., Zhang, J., Wang, X., 2015. Effects of alkalinity sources on the stability of anaerobic digestion from food waste. Waste Manag. Res. 33, 1033-1040. https://doi.org/10.1177/0734242X15602965

Chen, Y., Cheng, J.J., Creamer, K.S., 2008. Inhibition of anaerobic digestion process: A review. Bioresour. Technol. 99, 4044-4064. https://doi.org/10.1016/J.BIORTECH.2007.01.057

Cirne, D.G., Paloumet, X., Björnsson, L., Alves, M.M., Mattiasson, B., 2007. Anaerobic digestion of lipid-rich waste-Effects of lipid concentration. Renew. Energy 32, 965975. https://doi.org/10.1016/J.RENENE.2006.04.003 
534 Fotidis, I.A., Wang, H., Fiedel, N.R., Luo, G., Karakashev, D.B., Angelidaki, I., 2014.

535

536

537

538

539

540

541

542

543

544

545

546

547

548

549

550

551

552

553

554

555

556

557

558

Bioaugmentation as a Solution To Increase Methane Production from an Ammonia-Rich Substrate. Environ. Sci. Technol. 48, 7669-7676. https://doi.org/10.1021/es5017075

Gáspár, M., Kálmán, G., Réczey, K., 2007. Corn fiber as a raw material for hemicellulose and ethanol production. Process Biochem. 42, 1135-1139.

https://doi.org/10.1016/J.PROCBIO.2007.04.003

Gómez, X., Cuetos, M.J., Cara, J., Morán, A., García, A.I., 2006. Anaerobic co-digestion of primary sludge and the fruit and vegetable fraction of the municipal solid wastes: Conditions for mixing and evaluation of the organic loading rate. Renew. Energy 31, 2017-2024. https://doi.org/10.1016/J.RENENE.2005.09.029

Hussain, A., Dubey, S.K., 2017. Specific methanogenic activity test for anaerobic degradation of influents. Appl. Water Sci. 7, 535-542. https://doi.org/10.1007/s13201-015-0305-Z

Jijai, S., Muleng, S., Siripatana, C., 2017. Effect of dilution and ash supplement on the biomethane potential of palm oil mill effluent (POME). AIP Conf. Proc. 1868, 20013. https://doi.org/10.1063/1.4995099

Joo-Hwa, T., Xiyue, Z., 2000. Stability of High-Rate Anaerobic Systems. I: Performance under Shocks. J. Environ. Eng. 126, 713-725. https://doi.org/10.1061/(ASCE)07339372(2000)126:8(713)

Jun, D., Yong-sheng, Z., Mei, H., Wei-hong, Z., 2009. Influence of alkalinity on the stabilization of municipal solid waste in anaerobic simulated bioreactor. J. Hazard. Mater. 163, 717-722. https://doi.org/10.1016/J.JHAZMAT.2008.07.066

Kumar, P., Pant, D.C., Mehariya, S., Sharma, R., Kansal, A., Kalia, V.C., 2014. Ecobiotechnological strategy to enhance efficiency of bioconversion of wastes into hydrogen and methane. Indian J. Microbiol. 54, 262-267. https://doi.org/10.1007/s12088014-0467-7 
559

560

561

562

563

564

565

566

567

568

569

570

571

572

573

574

575

576

577

578

579

580

581

582

583

584

Lay, J.J., Li, Y.Y., Noike, T., Endo, J., Ishimoto, S., 1997. Analysis of environmental factors affecting methane production from high-solids organic waste. Water Sci. Technol. 36, 493-500. https://doi.org/10.2166/wst.1997.0628

Lee, H., Shoda, M., 2008. Stimulation of anaerobic digestion of thickened sewage sludge by iron-rich sludge produced by the fenton method. J. Biosci. Bioeng. 106, 107-110. https://doi.org/10.1263/JBB.106.107

Lens, P.N.., Klijn, R., van Lier, J.., Lettinga, G., 2003. Effect of specific gas loading rate on thermophilic $\left(55^{\circ} \mathrm{C}\right)$ acidifying $(\mathrm{pH} 6)$ and sulfate reducing granular sludge reactors. Water Res. 37, 1033-1047. https://doi.org/10.1016/S0043-1354(02)00459-1

Levén, L., Eriksson, A.R.B., Schnürer, A., 2007. Effect of process temperature on bacterial and archaeal communities in two methanogenic bioreactors treating organic household waste. FEMS Microbiol. Ecol. 59, 683-693.

Li, Q., Li, Y.-Y., Qiao, W., Wang, X., Takayanagi, K., 2015. Sulfate addition as an effective method to improve methane fermentation performance and propionate degradation in thermophilic anaerobic co-digestion of coffee grounds, milk and waste activated sludge with AnMBR. Bioresour. Technol. 185, 308-315. https://doi.org/10.1016/j.biortech.2015.03.019

Li, R., Chen, S., Li, X., Saifullah Lar, J., He, Y., Zhu, B., 2009. Anaerobic Codigestion of Kitchen Waste with Cattle Manure for Biogas Production. Energy \& Fuels 23, 2225 2228. https://doi.org/10.1021/ef8008772

Li, Y., Li, L., Sun, Y., Yuan, Z., 2018. Bioaugmentation strategy for enhancing anaerobic digestion of high $\mathrm{C} / \mathrm{N}$ ratio feedstock with methanogenic enrichment culture. Bioresour. Technol. 261, 188-195. https://doi.org/10.1016/J.BIORTECH.2018.02.069

Liu, C., Li, H., Zhang, Y., Chen, Q., 2016. Characterization of methanogenic activity during high-solids anaerobic digestion of sewage sludge. Biochem. Eng. J. 109, 96-100. https://doi.org/10.1016/J.BEJ.2016.01.010 
585 Menardo, S., Gioelli, F., Balsari, P., 2011. The methane yield of digestate: Effect of organic

586

587

588

589

590

591

592

593

594

595

596

597

598

601

602

603

604

605

606

607

608

609

610

611 loading rate, hydraulic retention time, and plant feeding. Bioresour. Technol. 102, 23482351. https://doi.org/10.1016/J.BIORTECH.2010.10.094

Nopharatana, A., Pullammanappallil, P.C., Clarke, W.P., 2007. Kinetics and dynamic modelling of batch anaerobic digestion of municipal solid waste in a stirred reactor. Waste Manag. 27, 595-603. https://doi.org/10.1016/J.WASMAN.2006.04.010

O-Thong, S., Suksong, W., Promnuan, K., Thipmunee, M., Mamimin, C., Prasertsan, P., 2016. Two-stage thermophilic fermentation and mesophilic methanogenic process for biohythane production from palm oil mill effluent with methanogenic effluent recirculation for $\mathrm{pH}$ control. Int. J. Hydrogen Energy 41, 21702-21712. https://doi.org/10.1016/j.ijhydene.2016.07.095

Oh, S.Y., Heo, N.S., Shukla, S., Kang, S.-M., Lee, I., Lee, H., Bajpai, V.K., Jang, S.-C., Han, Y.-K., Roh, C., Huh, Y.S., 2018. Multi-stress radioactive-tolerant Exiguobacterium acetylicum CR1 and its applicability to environmental cesium uptake bioremediation. J. Clean. Prod. 205, 281-290. https://doi.org/10.1016/J.JCLEPRO.2018.09.077

Prasertsan, P., O-Thong, S., Birkeland, N.K., 2009. Optimization and microbial community analysis for production of biohydrogen from palm oil mill effluent by thermophilic fermentative process. Int. J. Hydrogen Energy 34, 7448-7459. https://doi.org/10.1016/j.ijhydene.2009.04.075

Qiang, H., Niu, Q., Chi, Y., Li, Y., 2013. Trace metals requirements for continuous thermophilic methane fermentation of high-solid food waste. Chem. Eng. J. 222, 330336. https://doi.org/10.1016/J.CEJ.2013.02.076

Raposo, F., Banks, C.J., Siegert, I., Heaven, S., Borja, R., 2006. Influence of inoculum to substrate ratio on the biochemical methane potential of maize in batch tests. Process Biochem. 41, 1444-1450. https://doi.org/10.1016/j.procbio.2006.01.012

Raposo, F., Borja, R., Cacho, J.A., Mumme, J., Mohedano, Á.F., Battimelli, A., Bolzonella, D., Schuit, A.D., Noguerol-Arias, J., Frigon, J.-C., Peñuela, G.A., Muehlenberg, J., 
612

613

614

615

616

617

618

619

620

621

622

623

624

625

626

627

628

629

630

631

632

633

634

635

636

Sambusiti, C., 2015. Harmonization of the quantitative determination of volatile fatty acids profile in aqueous matrix samples by direct injection using gas chromatography and high-performance liquid chromatography techniques: Multi-laboratory validation study. J. Chromatogr. A 1413, 94-106. https://doi.org/10.1016/J.CHROMA.2015.08.008

Salminen, E., Rintala, J., 2002. Anaerobic digestion of organic solid poultry slaughterhouse waste - a review. Bioresour. Technol. 83, 13-26. https://doi.org/10.1016/S09608524(01)00199-7

Saritpongteeraka, K., Chaiprapat, S., 2008. Effects of $\mathrm{pH}$ adjustment by parawood ash and effluent recycle ratio on the performance of anaerobic baffled reactors treating high sulfate wastewater. Bioresour. Technol. 99, 8987-8994. https://doi.org/10.1016/J.BIORTECH.2008.05.012

Sosnowski, P., Klepacz-Smolka, A., Kaczorek, K., Ledakowicz, S., 2008. Kinetic investigations of methane co-fermentation of sewage sludge and organic fraction of municipal solid wastes. Bioresour. Technol. 99, 5731-5737. https://doi.org/10.1016/J.BIORTECH.2007.10.019

Supaphol, S., Jenkins, S.N., Intomo, P., Waite, I.S., O’Donnell, A.G., 2011. Microbial community dynamics in mesophilic anaerobic co-digestion of mixed waste. Bioresour. Technol. 102, 4021-4027. https://doi.org/10.1016/J.BIORTECH.2010.11.124

Tangchirapat, W., Jaturapitakkul, C., Chindaprasirt, P., 2009. Use of palm oil fuel ash as a supplementary cementitious material for producing high-strength concrete. Constr. Build. Mater. 23, 2641-2646. https://doi.org/10.1016/J.CONBUILDMAT.2009.01.008

Tatusova, T., Dicuccio, M., Badretdin, A., Chetvernin, V., Nawrocki, E.P., Zaslavsky, L., Lomsadze, A., Pruitt, K.D., Borodovsky, M., Ostell, J., 2016. NCBI prokaryotic genome annotation pipeline. Nucleic Acids Res. 44, 6614-6624. https://doi.org/10.1093/nar/gkw569 
637 Trzcinski, A.P., Ray, M.J., Stuckey, D.C., 2010. Performance of a three-stage membrane

638

639

640

641

642

643

644

645

646

647

648

649

650

651

652

653

654

655

656

657

658

659

660

661

662 bioprocess treating the organic fraction of municipal solid waste and evolution of its archaeal and bacterial ecology. Bioresour. Technol. 101, 1652-1661.

Voelklein, M.A., O' Shea, R., Jacob, A., Murphy, J.D., 2017. Role of trace elements in single and two-stage digestion of food waste at high organic loading rates. Energy 121, 185192. https://doi.org/10.1016/J.ENERGY.2017.01.009

Wirth, R., Kovács, E., Maróti, G., Bagi, Z., Rákhely, G., Kovács, K.L., 2012. Characterization of a biogas-producing microbial community by short-read next generation DNA sequencing. Biotechnol. Biofuels 5, 41. https://doi.org/10.1186/1754$6834-5-41$

Wongfaed, N., Kongjan, P., O-Thong, S., 2015. Effect of Substrate and Intermediate Composition on Foaming in Palm Oil Mill Effluent Anaerobic Digestion System. Energy Procedia 79, 930-936. https://doi.org/10.1016/j.egypro.2015.11.589

Wongfaed, N., Kongjan, P., Prasertsan, P., O-Thong, S., 2020. Effect of oil and derivative in palm oil mill effluent on the process imbalance of biogas production. J. Clean. Prod. 247, 119110. https://doi.org/10.1016/J.JCLEPRO.2019.119110

Wu, L.-J., Kobayashi, T., Kuramochi, H., Li, Y.-Y., Xu, K.-Q., 2015. Recovery strategies of inhibition for mesophilic anaerobic sludge treating the de-oiled grease trap waste. Int. Biodeterior. Biodegradation 104, 315-323. https://doi.org/10.1016/J.IBIOD.2015.06.020

Wu, T.Y., Mohammad, A.W., Jahim, J.M., Anuar, N., 2010. Pollution control technologies for the treatment of palm oil mill effluent (POME) through end-of-pipe processes. J. Environ. Manage. 91, 1467-1490. https://doi.org/10.1016/J.JENVMAN.2010.02.008

Xia, Y., Massé, D.I., Mcallister, T.A., Kong, Y., Seviour, R., Beaulieu, C., 2012. Identity and diversity of archaeal communities during anaerobic co-digestion of chicken feathers and other animal wastes. Bioresour. Technol. 110, 111-119. https://doi.org/10.1016/j.biortech.2012.01.107 
663 Yan, Z., Song, Z., Li, D., Yuan, Y., Liu, X., Zheng, T., 2015. The effects of initial substrate

664

665

666

667

668

669

670

671

672

673

674

675

676

677

678

679

680

681

682

683

684

685

686

687

688

689 concentration, $\mathrm{C} / \mathrm{N}$ ratio, and temperature on solid-state anaerobic digestion from composting rice straw. Bioresour. Technol. 177, 266-273. https://doi.org/10.1016/J.BIORTECH.2014.11.089

Yang, Z.-H., Xu, R., Zheng, Y., Chen, T., Zhao, L.-J., Li, M., 2016. Characterization of extracellular polymeric substances and microbial diversity in anaerobic co-digestion reactor treated sewage sludge with fat, oil, grease. Bioresour. Technol. 212, 164-173. https://doi.org/10.1016/J.BIORTECH.2016.04.046

Zhang, J., Wang, Q., Jiang, J., 2013. Lime mud from paper-making process addition to food waste synergistically enhances hydrogen fermentation performance. Int. J. Hydrogen Energy 38, 2738-2745. https://doi.org/10.1016/J.IJHYDENE.2012.12.048

Zhang, J., Wang, Q., Zheng, P., Wang, Y., 2014. Anaerobic digestion of food waste stabilized by lime mud from papermaking process. Bioresour. Technol. 170, 270-277. https://doi.org/10.1016/J.BIORTECH.2014.08.003

Zhang, W., Xing, W., Li, R., 2018. Real-time recovery strategies for volatile fatty acidinhibited anaerobic digestion of food waste for methane production. Bioresour. Technol. 265, 82-92. https://doi.org/10.1016/j.biortech.2018.05.098

Zhang, X., Qiu, W., Chen, H., 2012. Enhancing the hydrolysis and acidification of steamexploded cornstalks by intermittent $\mathrm{pH}$ adjustment with an enriched microbial community. Bioresour. Technol. 123, 30-35. https://doi.org/10.1016/J.BIORTECH.2012.07.054

Zhang, Z., Zhang, G., Li, W., Li, C., Xu, G., 2016. Enhanced biogas production from sorghum stem by co-digestion with cow manure. Int. J. Hydrogen Energy 41, 9153-9158. https://doi.org/10.1016/J.IJHYDENE.2016.02.042

Zhu, J., Wan, C., Li, Y., 2010. Enhanced solid-state anaerobic digestion of corn stover by alkaline pretreatment. Bioresour. Technol. 101, 7523-7528. https://doi.org/10.1016/j.biortech.2010.04.060 
690 This work is no conflict of interest. 
Figure 1

Specific methanogenic activity (SMA) of the inhibited sludge and recovered sludge by different recovery strategies.

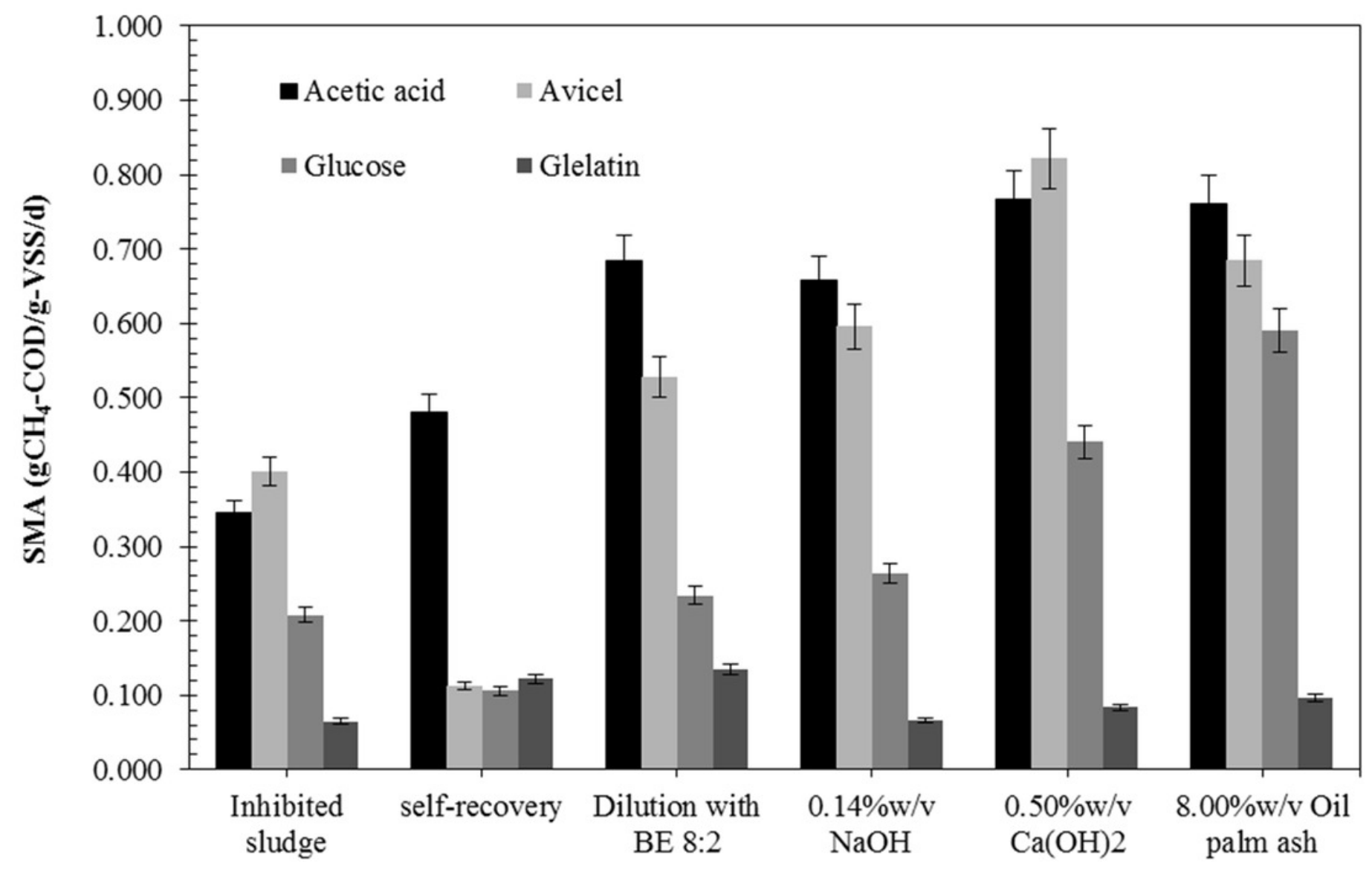


Figure 2

Full-scale application for recovery inhibited sludge by dilution with biogas effluent at a ratio of $8: 2$.

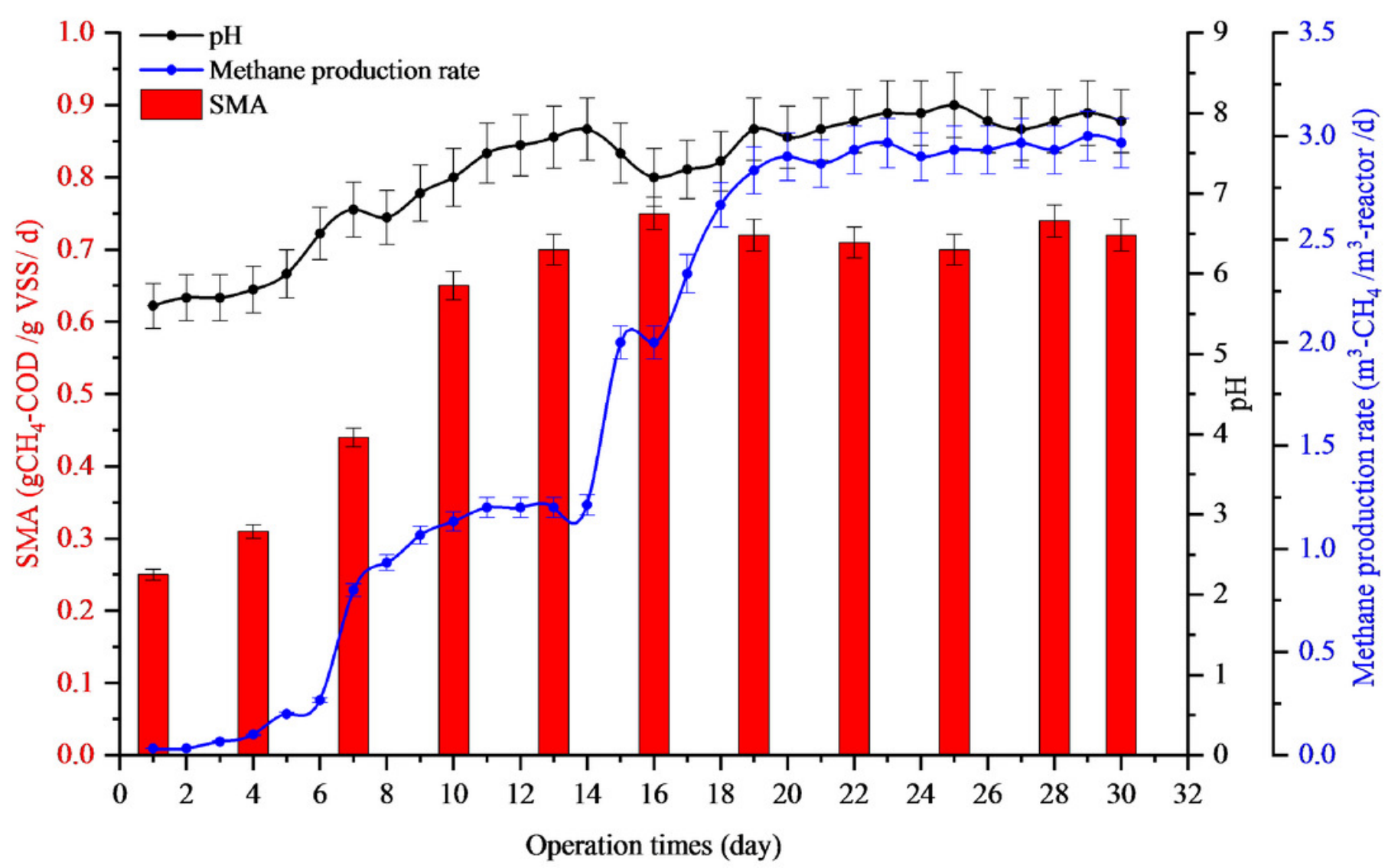


Figure 3

Dynamic diversity of bacteria (A) and archaea (B) during recovery by self-recovery, dilution with $\mathrm{BE} 8: 2,0.14 \% \mathrm{w} / \mathrm{v} \mathrm{NaOH}$ addition, $0.50 \% \mathrm{w} / \mathrm{v} \mathrm{Ca}(\mathrm{OH})_{2}$ addition , and $8.00 \%$ $\mathrm{w} / \mathrm{v}$ oil palm ash addition.

The size of the rectangle respect to the dominance of microorganisms is represented from long-size to short-size for strong dominant to low dominant of microorganisms, respectively. 


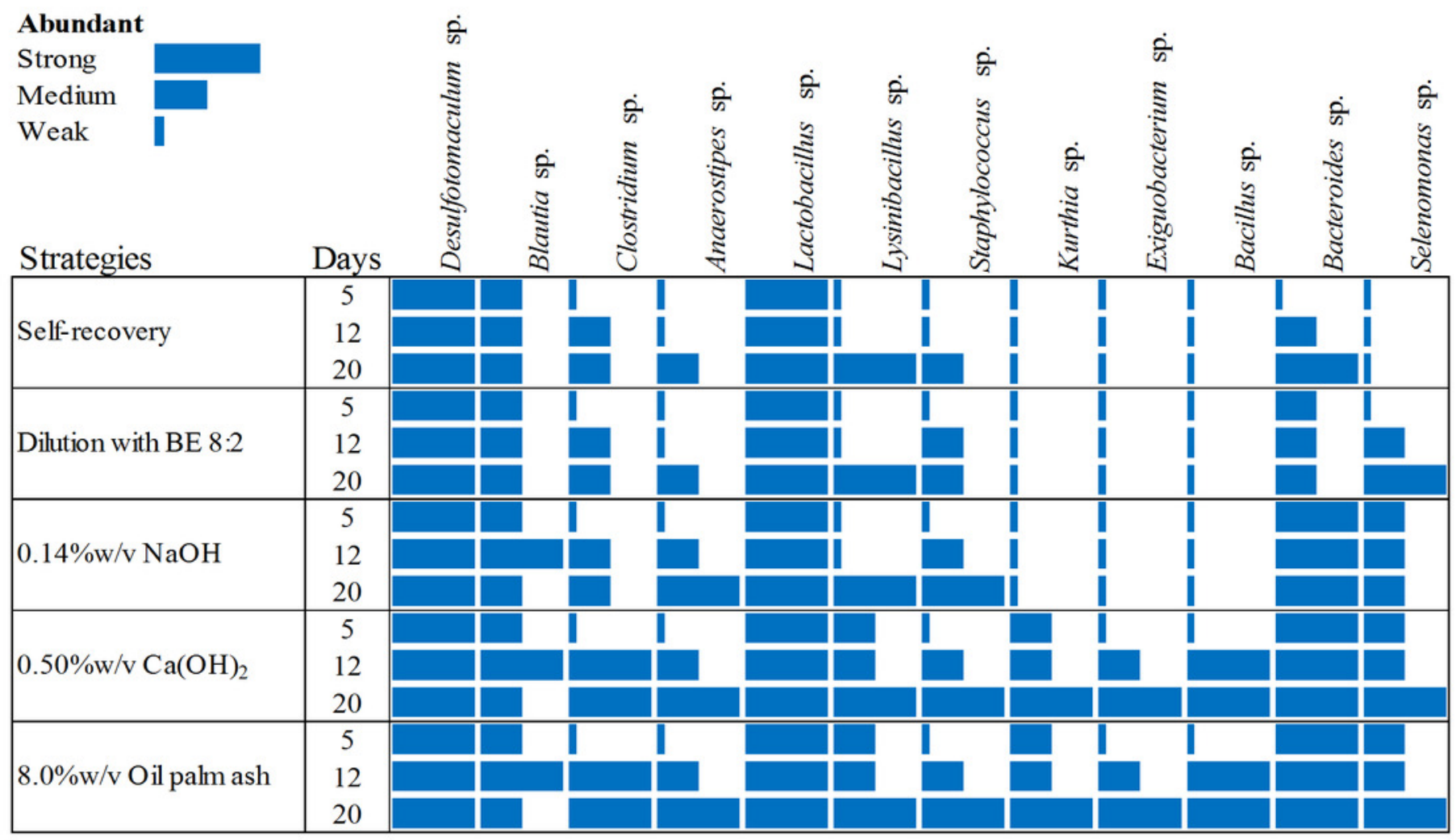

\begin{tabular}{|c|c|c|c|c|c|}
\hline Strategies & Days & 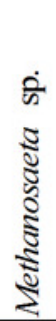 &  & 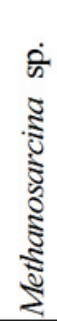 & 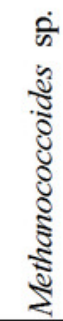 \\
\hline Self-recovery & $\begin{array}{c}5 \\
12 \\
20\end{array}$ & & & & \\
\hline Dilution with BE 8:2 & $\begin{array}{c}5 \\
12 \\
20\end{array}$ & & & & \\
\hline $0.14 \% w / v \mathrm{NaOH}$ & $\begin{array}{c}5 \\
12 \\
20\end{array}$ & & & & \\
\hline $0.50 \% \mathrm{w} / \mathrm{v} \mathrm{Ca}(\mathrm{OH})_{2}$ & $\begin{array}{c}5 \\
12 \\
20\end{array}$ & & & & \\
\hline $8.0 \% \mathrm{w} / \mathrm{v}$ Oil palm ash & $\begin{array}{c}5 \\
12 \\
20\end{array}$ & & & & \\
\hline
\end{tabular}




\section{Table 1 (on next page)}

The characteristics of inhibited sludge, active methane-producing sludge, POME, and biogas effluent. 
1 Table 1. The characteristics of inhibited sludge, active methane-producing sludge, POME, and biogas effluent.

\begin{tabular}{lccccc}
\hline Parameter & Unit & POME & $\begin{array}{c}\text { Biogas } \\
\text { effluent }\end{array}$ & $\begin{array}{c}\text { Active methane- } \\
\text { producing } \\
\text { sludge }\end{array}$ & $\begin{array}{c}\text { Inhibited } \\
\text { sludge }\end{array}$ \\
& & & & & $7.5 \pm 0.1$ \\
$\mathrm{pH}$ & - & $4.1 \pm 0.1$ & $7.8 \pm 0.1$ & $68.4 \pm 0.3$ & $24.0 \pm 0.2$ \\
Total solids (TS) & $\mathrm{g} / \mathrm{L}$ & $55.4 \pm 0.2$ & $13.4 \pm 0.3$ & $61.5 \pm 0.2$ & $17.0 \pm 0.1$ \\
Volatile solids (VS) & $\mathrm{g} / \mathrm{L}$ & $45.1 \pm 0.3$ & $4.8 \pm 0.2$ & $59.8 \pm 0.1$ & $14.5 \pm 0.2$ \\
Suspended solids (SS) & $\mathrm{g} / \mathrm{L}$ & $34 \pm 0.3$ & $2.4 \pm 0.3$ & $52.2 \pm 0.3$ & $11.0 \pm 0.3$ \\
Volatile suspended solids (VSS) & $\mathrm{g} / \mathrm{L}$ & $17.0 \pm 1.2$ & $1.3 \pm 0.4$ & $2.5 \pm 0.4$ & $0.7 \pm 0.2$ \\
Total nitrogen (TN) & $\mathrm{g} / \mathrm{L}$ & $1.2 \pm 0.2$ & $0.2 \pm 0.3$ & $6.1 \pm 0.1$ & $2.4 \pm 0.2$ \\
Alkalinity & $\mathrm{g} / \mathrm{L}$ as & $2.9 \pm 0.2$ & $3.9 \pm 0.2$ & & $4.4 \pm 0.1$ \\
& $\mathrm{CaCO}$ & & & $0.5 \pm 0.1$ & $28.9 \pm 0.2$ \\
Lipid & $\mathrm{g} / \mathrm{L}$ & $6.5 \pm 0.3$ & $0.1 \pm 0.02$ & $\mathrm{~N} . \mathrm{D}$. & $23.9 \pm 0.3$ \\
Total chemical oxygen demand (tCOD) & $\mathrm{g} / \mathrm{L}$ & $59.0 \pm 0.1$ & $7.5 \pm 0.1$ & $2.5 \pm 0.2$ & $4.8 \pm 0.1$ \\
Soluble chemical oxygen demand (sCOD) & $\mathrm{g} / \mathrm{L}$ & $38.2 \pm 0.3$ & $1.2 \pm 0.3$ & $0.9 \pm 0.3$ & $1.8 \pm 0.2$ \\
Total volatile fatty acids (TVFAs) & $\mathrm{g} / \mathrm{L}$ & $1.3 \pm 0.1$ & $0.2 \pm 0.2$ & $0.3 \pm 0.01$ & $1.4 \pm 0.1$ \\
Acetic acid & $\mathrm{g} / \mathrm{L}$ & $0.4 \pm 0.04$ & $0.02 \pm 0.01$ & $0.07 \pm 0.02$ & $0.3 \pm 0.1$ \\
Propionic acid & $\mathrm{g} / \mathrm{L}$ & $0.06 \pm 0.01$ & $0.05 \pm 0.02$ & $0.05 \pm 0.01$ & $2.5 \pm 0.1$ \\
Isobutyric acid & $\mathrm{g} / \mathrm{L}$ & $0.03 \pm 0.01$ & $0.03 \pm 0.01$ & $0.5 \pm 0.04$ & \\
Butyric acid & $\mathrm{g} / \mathrm{L}$ & $0.6 \pm 0.05$ & $0.02 \pm 0.01$ & &
\end{tabular}

3 Note: N.D. $=$ Not determined 
Table 2 (on next page)

Performance of self-recovery and recovered sludge by various strategies.

The colors respect to the high performances in dark red to low performance in light red. 
1 Table 2. Performance of self-recovery and recovered sludge by various strategies with the colors respect to the high performances in 2 dark red to low performance in light red.

\begin{tabular}{|c|c|c|c|c|c|c|c|}
\hline Strategies & Initial $\mathrm{pH}$ & Final $\mathrm{pH}$ & $\begin{array}{c}\text { Methane yield }\left(\mathrm{mL}^{-} \mathrm{CH}_{4} / \mathrm{g}-\right. \\
\left.\mathrm{VS}_{\text {added }}\right)\end{array}$ & $\begin{array}{l}\text { Methane Production rate (mL- } \\
\mathrm{CH}_{4} / \mathrm{d} \text { ) }\end{array}$ & $\begin{array}{c}k_{H}\left(\mathrm{~d}^{-}\right. \\
1)\end{array}$ & $\begin{array}{l}\text { Lag phase } \\
\text { (d) }\end{array}$ & $\begin{array}{l}\text { Recovery time } \\
\text { (d) }\end{array}$ \\
\hline Self-recovery & 5.7 & 7.8 & 209 & 40.8 & 0.005 & 21.2 & 49.4 \\
\hline Dilution with TW 9:1 & 6.2 & 7.3 & 190 & 42.7 & 0.007 & 15.1 & 41.7 \\
\hline Dilution with TW 8:2 & 6.3 & 7.4 & 187 & 40.6 & 0.006 & 12.4 & 39.2 \\
\hline Dilution with TW 7:3 & 6.3 & 7.4 & 178 & 46.0 & 0.007 & 14.3 & 38.1 \\
\hline Dilution with TW 6:4 & 6.5 & 7.5 & 173 & 46.4 & 0.007 & 10.9 & 36.5 \\
\hline Dilution with TW 5:5 & 6.5 & 7.5 & 177 & 62.5 & 0.006 & 9.9 & 33.2 \\
\hline Dilution with BE 9:1 & 6.7 & 7.3 & 214 & 53.4 & 0.008 & 12.3 & 42.0 \\
\hline Dilution with BE 8:2 & 6.8 & 7.4 & 282 & 91.4 & 0.009 & 7.1 & 36.4 \\
\hline Dilution with BE $7: 3$ & 6.9 & 7.5 & 253 & 108.0 & 0.008 & 7.7 & 30.8 \\
\hline Dilution with BE 6:4 & 6.5 & 7.6 & 229 & 100.4 & 0.009 & 7.2 & 31.2 \\
\hline Dilution with BE 5:5 & 6.5 & 7.8 & 230 & 92.8 & 0.008 & 9.9 & 32.8 \\
\hline $0.10 \% \mathrm{w} / \mathrm{v} \mathrm{NaOH}$ & 6.5 & 8.6 & 218 & 85.9 & 0.007 & 9.5 & 30.8 \\
\hline $0.11 \% \mathrm{w} / \mathrm{v} \mathrm{NaOH}$ & 6.6 & 8.8 & 238 & 87.3 & 0.007 & 9.5 & 30.0 \\
\hline $0.12 \% \mathrm{w} / \mathrm{v} \mathrm{NaOH}$ & 6.8 & 8.8 & 278 & 87.0 & 0.006 & 8.9 & 35.0 \\
\hline $0.13 \% \mathrm{w} / \mathrm{v} \mathrm{NaOH}$ & 7.0 & 8.2 & 263 & 85.9 & 0.006 & 9.1 & 34.1 \\
\hline $0.14 \% \mathrm{w} / \mathrm{v} \mathrm{NaOH}$ & 7.3 & 8.5 & 383 & 111.7 & 0.006 & 9.0 & 35.0 \\
\hline $0.85 \% \mathrm{w} / \mathrm{v} \mathrm{NaHCO}_{3}$ & 6.7 & 7.2 & 223 & 31.8 & 0.004 & 14.0 & 45.8 \\
\hline $1.00 \% \mathrm{w} / \mathrm{v} \mathrm{NaHCO}_{3}$ & 6.8 & 7.3 & 224 & 24.2 & 0.004 & 14.0 & 58.8 \\
\hline $1.25 \% \mathrm{w} / \mathrm{v} \mathrm{NaHCO} 3$ & 6.9 & 7.5 & 268 & 27.2 & 0.005 & 14.0 & 61.6 \\
\hline $1.45 \% \mathrm{w} / \mathrm{v} \mathrm{NaHCO}_{3}$ & 6.9 & 7.6 & 168 & 20.8 & 0.004 & 16.0 & 58.5 \\
\hline $1.50 \% \mathrm{w} / \mathrm{v} \mathrm{NaHCO}_{3}$ & 7.0 & 7.7 & 158 & 22.0 & 0.004 & 16.0 & 53.4 \\
\hline $0.10 \% \mathrm{w} / \mathrm{v} \mathrm{Ca}(\mathrm{OH})_{2}$ & 6.7 & 8.1 & 319 & 103.8 & 0.008 & 7.6 & 36.7 \\
\hline $0.20 \% \mathrm{w} / \mathrm{v} \mathrm{Ca}(\mathrm{OH})_{2}$ & 6.8 & 8.1 & 333 & 129.5 & 0.007 & 9.0 & 35.3 \\
\hline $0.30 \% \mathrm{w} / \mathrm{v} \mathrm{Ca}(\mathrm{OH})_{2}$ & 6.8 & 8.0 & 368 & 112.0 & 0.007 & 8.3 & 35.3 \\
\hline $0.40 \% \mathrm{w} / \mathrm{v} \mathrm{Ca}(\mathrm{OH})_{2}$ & 7.0 & 8.3 & 373 & 151.4 & 0.008 & 9.1 & 33.8 \\
\hline $0.50 \% \mathrm{w} / \mathrm{v} \mathrm{Ca}(\mathrm{OH})_{2}$ & 7.1 & 8.6 & 360 & 137.7 & 0.006 & 9.4 & 33.9 \\
\hline $6.00 \% \mathrm{w} / \mathrm{v}$ Oil palm ash & 6.5 & 7.5 & 239 & 155.4 & 0.007 & 7.9 & 33.2 \\
\hline $7.00 \% \mathrm{w} / \mathrm{v}$ Oil palm ash & 6.9 & 7.8 & 265 & 155.2 & 0.006 & 8.6 & 32.1 \\
\hline $8.00 \% \mathrm{w} / \mathrm{v}$ Oil palm ash & 6.9 & 8.0 & 347 & 226.3 & 0.007 & 8.2 & 32.4 \\
\hline $9.00 \% \mathrm{w} / \mathrm{v}$ Oil palm ash & 6.9 & 8.3 & 218 & 147.5 & 0.006 & 9.2 & 33.0 \\
\hline $10.00 \% \mathrm{w} / \mathrm{v}$ Oil palm ash & 6.9 & 8.7 & 211 & 152.2 & 0.006 & 9.1 & 32.5 \\
\hline
\end{tabular}




\section{Table 3(on next page)}

Performance of recovered sludge by addition of active methane-producing sludge.

The colors respect to the high performances in dark red to low performance in light red. 
1 Table 3. Performance of recovered sludge by addition of active methane-producing sludge with the colors respect to the high performances in dark red to low performance in light red.

\begin{tabular}{cccccccc}
\hline $\begin{array}{c}\text { Active methane-producing } \\
\text { sludge } \\
(\% \mathrm{v} / \mathrm{v})\end{array}$ & $\begin{array}{c}\text { Initial } \\
\mathrm{pH}\end{array}$ & $\begin{array}{c}\text { Final } \\
\mathrm{pH}\end{array}$ & $\begin{array}{c}\text { Methane yield } \\
\left(\mathrm{mL}_{-} \mathrm{CH}_{4} / \mathrm{g}-\mathrm{VS}_{\mathrm{added}}\right)\end{array}$ & $\begin{array}{c}\text { Methane production } \\
\text { rate } \\
\left(\mathrm{mL}-\mathrm{CH}_{4} / \mathrm{d}\right)\end{array}$ & $\begin{array}{c}k_{H} \\
\left(\mathrm{~d}^{-1}\right)\end{array}$ & $\begin{array}{c}\text { Lag } \\
\text { phase } \\
(\mathrm{d})\end{array}$ & $\begin{array}{c}\text { Recovery } \\
\text { time } \\
(\mathrm{d})\end{array}$ \\
\hline 5 & & & & & 40.4 & 0.007 & 15.2 \\
10 & 6.4 & 7.5 & 212 & 47.2 & 0.007 & 15.1 & 45.8 \\
15 & 6.4 & 7.5 & 216 & 60.8 & 0.007 & 15.0 & 47.2 \\
20 & 6.4 & 7.5 & 214 & 77.0 & 0.006 & 15.0 & 45.2 \\
25 & 6.4 & 7.5 & 222 & 70.7 & 0.006 & 15.0 & 44.2 \\
30 & 6.4 & 7.5 & 222 & 65.9 & 0.006 & 13.2 & 43.6 \\
35 & 6.4 & 7.6 & 224 & 67.9 & 0.006 & 12.0 & 43.9 \\
40 & 6.4 & 7.6 & 222 & 80.9 & 0.006 & 12.0 & 44.0 \\
45 & 6.4 & 7.6 & 227 & 80.1 & 0.007 & 11.0 & 44.5 \\
50 & 6.4 & 7.9 & 230 & 83.5 & 0.008 & 11.0 & 45.8 \\
\hline
\end{tabular}




\section{Table 4 (on next page)}

The economic evaluation and energy balance of different recovery strategies. 
1 Table 4. The economic evaluation of different strategies for the recovery of the imbalanced AD

2 reactor.

\begin{tabular}{|c|c|c|c|c|c|c|}
\hline Items & $\begin{array}{c}\text { Dilution } \\
\text { with tap } \\
\text { water }(\mathrm{TW})\end{array}$ & $\begin{array}{l}\text { Dilution with } \\
\text { biogas } \\
\text { effluent (BE) }\end{array}$ & $\begin{array}{l}\mathrm{NaOH} \\
\text { addition }\end{array}$ & $\begin{array}{l}\mathrm{Ca}(\mathrm{OH})_{2} \\
\text { addition }\end{array}$ & $\begin{array}{c}\mathrm{NaHCO}_{3} \\
\text { addition }\end{array}$ & $\begin{array}{l}\text { Oil palm } \\
\text { ash } \\
\text { addition }\end{array}$ \\
\hline $\begin{array}{l}\text { Chemical } \\
\text { addition cost } \\
\left(\mathrm{USD} / \mathrm{m}^{3} / \mathrm{d}\right)\end{array}$ & -0.02 & 0.00 & -0.49 & -0.19 & -1.73 & 0.00 \\
\hline $\begin{array}{l}\text { Human resource } \\
\text { cost }\left(\mathrm{USD} / \mathrm{m}^{3} / \mathrm{d}\right)\end{array}$ & -0.05 & -0.05 & -0.15 & -0.15 & -0.15 & -0.15 \\
\hline $\begin{array}{l}\text { Energy } \\
\text { consumption } \\
\left(\mathrm{USD} / \mathrm{m}^{3} / \mathrm{d}\right)\end{array}$ & -0.10 & -0.10 & -0.02 & -0.02 & -0.02 & -0.02 \\
\hline $\begin{array}{l}\text { Biogas loss } \\
\left(\mathrm{USD} / \mathrm{m}^{3} / \mathrm{d}\right)\end{array}$ & -4.26 & -3.46 & -3.20 & -3.73 & -5.30 & -3.46 \\
\hline $\begin{array}{l}\text { Biogas } \\
\text { production } \\
\left(\mathrm{USD} / \mathrm{m}^{3} / \mathrm{d}\right)\end{array}$ & 1.04 & 1.84 & 2.10 & 1.60 & 0.00 & 1.84 \\
\hline $\begin{array}{l}\text { Net profit } \\
\left(\mathrm{USD} / \mathrm{m}^{3} / \mathrm{d}\right)\end{array}$ & -3.39 & -1.77 & -1.76 & -2.49 & -7.20 & -1.79 \\
\hline
\end{tabular}

3 